Summer 8-22-2020

\title{
Implementing Hospital-Acquired Pressure Injury (HAPI) Prevention Program
}

\author{
Marisa Raynaldo \\ University of St. Augustine for Health Sciences, m.raynaldo@usa.edu \\ DOI: https://doi.org/10.46409/sr.RIDN4317
}

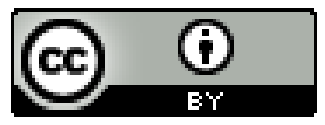

This work is licensed under a Creative Commons Attribution 4.0 License.

Follow this and additional works at: https://soar.usa.edu/scholprojects

Part of the Health and Medical Administration Commons, and the Nursing Commons

\section{Recommended Citation \\ Raynaldo, M. (2020). Implementing Hospital-Acquired Pressure Injury (HAPI) Prevention Program. [Doctoral project, University of St Augustine for Health Sciences]. SOAR @ USA: Student Scholarly Projects Collection. https://doi.org/10.46409/sr.RIDN4317}

This Scholarly Project is brought to you for free and open access by the Student Research at SOAR @ USA. It has been accepted for inclusion in Student Scholarly Projects by an authorized administrator of SOAR @ USA. For more information, please contact soar@usa.edu, erobinson@usa.edu. 
Implementing Hospital-Acquired Pressure Injury (HAPI) Prevention Program Marisa C. Raynaldo

School of Nursing, University of St. Augustine for Health Sciences

This Manuscript Partially Fulfills the Requirements for the Doctor of Nursing Practice Program and is Approved by:

Douglas M. Turner, PhD, DNP, RN, CNE, NE-BC, NEA-BC Andrya R. Rivera-Burciaga, DNP, APRN, FNP-BC, ACHPN Date of Final Approval: April 4, 2020 


\section{University of St. Augustine for Health Sciences \\ DNP Scholarly Project \\ Signature Form}

\begin{tabular}{|l|l|l|}
\hline Student Last Name: & First Name: & Middle Initial: \\
Raynaldo & Marisa & C \\
\hline
\end{tabular}

E-mail:

m.raynaldo@usa.edu

Title of DNP Project:

Hospital-Acquired Pressure Injury Prevention Program

I have reviewed and approved this final written DNP Project. My typed name below serves as my electronic signature.

\begin{tabular}{|c|c|c|c|}
\hline Faculty/Preceptor Typed Name & $\begin{array}{l}\text { Electronic } \\
\text { Signature }\end{array}$ & Email Address & Date \\
\hline $\begin{array}{l}\text { DNP Project Primary Faculty: } \\
\text { Douglas M. Turner, PhD, RN }\end{array}$ & Doughas Tunser & dturner@usa.edu & $08 / 04 / 20$ \\
\hline \multicolumn{3}{|c|}{ 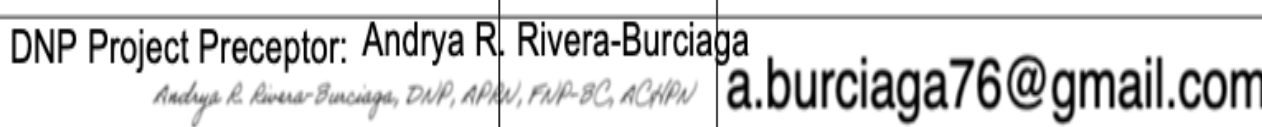 } & $08 / 04 / 20$ \\
\hline DNP Project Preceptor: & NA & $\mathrm{NA}$ & \\
\hline
\end{tabular}




\begin{abstract}
Practice Problem: Hospital-Acquired Pressure Injury (HAPI) is a serious problem in patient care and has deleterious implications for the patient and the healthcare system. A 530-bed acute care hospital in the Rio Grande Valley identified a similar challenge and implemented a HAPI preventive program.
\end{abstract}

PICOT: This evidence-based practice (EBP) project was guided by the following PICOT question: In the Intensive Care Unit/Medical Intensive Care Unit (ICU/MICU) patients aged 18 and older, does a pressure preventive bundle, compared to routine pressure injury care, reduce the incidence of pressure injury, within 21 days?

Evidence: The reviewed literature supported evidence of effective use of a pressure injury preventive bundle in reducing the incidence of pressure injuries in an acute care setting. Seven articles met the inclusion criteria and were used for this literature review.

Intervention: The evidence-based pressure injury preventive bundle are interventions that included consistent skin risk assessment and the application of a group of clinical practice guidelines composing of moisture management, optimizing nutrition and hydration and minimizing pressure, shear, and friction that were proven to prevent the occurrence of pressure injuries.

Outcome: Post-implementation findings showed that there was no reduction in the incidence of HAPI but significant decrease in the severity of the pressure injury from Stage two to Stage one. Conclusion: The staff education, training, and implementation of an evidence-based bundle intervention to prevent the incidence of HAPI proved a positive outcome on reducing the pressure injury severity from Stage Two pressure injuries to Stage One pressure injuries. 


\section{Implementing Hospital-Acquired Pressure Injury (HAPI) Prevention Program}

Pressure injuries (PIs) remain a major concern locally, nationally, and globally. In April 2016, the National Pressure Ulcer Advisory Panel (NPUAP) replaced the term pressure ulcer with pressure injury in the NPUAP Injury Staging System to reflect injuries in both intact and ulcerated skin (Edsberg et al., 2016). Pressure injuries are injuries to the skin and underlying tissues caused by constant pressure (Reilly, Karakousis, Schrag, \& Stawicki, 2007). Any prolonged and unrelieved pressure causes occlusion of blood flow, ischemia, and ultimately cell death. (Reilly et al., 2007).

HAPI is a serious problem in patient care and has deleterious implications for the patient and the healthcare system. HAPIs leads to enormous patient suffering as well as an excessively high healthcare expense. The Centers for Medicare and Medicaid Services (CMS) identifies PI as Never Events; an event that a patient should not incur while in the hospital and CMS no longer provides reimbursement for care related to these events (Armour-Burton, Fields, Outlaw, \& Deleon, 2013). Several evidence-based clinical practices have been implemented and adopted by healthcare organizations to prevent or reduce the incidence of pressure injury. The purpose of this EBP project is to decrease the incidence of HAPI by $15 \%$ over the three weeks of the introduction of the HAPI prevention bundle to the Intensive Care Unit/Medical Intensive Care Unit (ICU/MICU).

\section{Significance of the Practice Problem}

Pressure Injuries (PIs) are injuries to the skin or underlying tissues over bony prominences because of pressure, shear, and friction (Zuo \& Meng, 2015). PI remains a challenge worldwide. PIs harms patients by a longer recovery period, causing pain, potential infections, and increase in healthcare cost to both the patient and the hospital/healthcare setting 
(Grealy \& Chaboyer, 2012).

The need to decrease the incidence of HAPI in the ICU/MICU was vital. Data from the wound care system reported 127 HAPIs for 2018, which was an increase of 40 HAPIs from 2017. The financial impact of these Never Events is significant, with a cost ranging from $\$ 2,000$ $\$ 40,000$ per PI, depending on the stage of the PI (NPUAP, 2014). The cost alone, without the cost of human suffering, demonstrates the importance of preventing PIs and the importance of cost-effective, preventative practices (Ostadabbas et al., 2012). The scope of the problem is significant on multiple levels. Estimates indicated that one to three million people in the United States develop PIs each year (Kruger, Pires, Ngann, Sterling, \& Rubayi, 2013). The Joint Commission on Patient Safety estimates that more than 2.5 million patients in acute care facilities suffer from PIs and that 60,000 dies from PI-related complications each year (Kruger et al., 2013). The CMS penalty, potentially withholding reimbursement for Hospital Acquired Conditions (HAC), negatively affects the organization's finances.

\section{PICOT Question}

Most HAPIs are considered preventable and identified by the National Quality Forum (NQF) as a nurse-sensitive quality indicator (Spetz \& Brown, 2013). This DNP evidence-based practice project aimed to answer the following scholarly question: In the Intensive Care Unit/Medical Intensive Care Unit (ICU/MICU) patients aged 18 and older [P], does a pressure preventive bundle $[\mathrm{I}]$, compared to routine pressure injury care $[\mathrm{C}]$, reduce the incidence of pressure injury [O], within 21 days? [T].

\section{Population}

This EBP project target population consisted of adult ICU/MICU 31-bed unit within a 530 acute care facility. The project sample included 90 adult patients admitted in March 2020 
who received the routine pressure injury care.

\section{Setting}

The setting of the change project was a 31-bed ICU/MICU within a 530-bed acute care facility. The ICU/MICU unit admits critically ill cardiovascular patients, medical-surgical patients, post-open-heart patients, trauma patients, and other patients that meet criteria for admission to ICU/MICU. This was a closed unit, once a patient was admitted to ICU/MICU, the Critical Care Intensivist becomes the primary care/attending physician. These Intensivists can still consult other specialist physicians as needed.

\section{Pressure Injury Preventive Intervention}

This pressure injury preventive bundle intervention (PIPBI) was adopted from the Hospital-Acquired Pressure Ulcers/Injuries change package published by Health Research \& Educational Trust (HRET, 2017). The drivers in this change packet consist of five major components: 1) conduct skin and risk assessments, 2) manage moisture, 3) optimize nutrition and hydration, 4) minimize pressure, shear, and friction, and 5) education and training of staff. This change packet is used as a tool to make patient care safer and improve care transitions and is a product of high performing health organizations across the nation. It was developed through the sharing of clinical practice, subject matter expert contributions, and organization site visits. Additionally, the document is an easy guide because it includes a menu of strategies, change concepts, and actionable items that can be used based on need. The multidisciplinary team reviewed these strategies and agreed to some strategies that were applicable and met the ICU/MICU patient needs.

\section{Theoretical Framework}

Lewin's Change Theory and the Plan-Do-Study-Act (PDSA) model provided the 
framework for this preventive bundle project. Lewin's theory and its application are discussed first. Finally, the PDSA model by the Institute for Healthcare Improvement (IHI; 2019) guided the implementation and evaluation phase of this project.

\section{Lewin's Change Theory}

Lewin's Change Theory is a three-step change model (Kritsonis, 2005). This model facilitated the implementation of interventions to promote changes in the nursing staff. Lewin's Change Theory is a three-step change model (Kritsonis, 2005). This model facilitated the implementation of interventions to promote changes in the nursing staff. This model views behavior as the balancing of forces working in opposing directions; therefore, following the analysis of forces, the application of the three-step model can balance the direction of the change plan. Lewin's theory has three major concepts: driving forces, restraining forces, and equilibrium (Kritsonis, 2005). Driving forces are those that push in a direction that causes change to occur, facilitating the patient in the desired direction, and causes a shift in the equilibrium toward change. Restraining forces are those that counter the driving forces, causing a shift in the equilibrium that opposes change (Kritsonis, 2005). Lewin's theory proposed that change occurs in three stages: unfreezing, change, and refreezing/the freezing stage (Lewin, 2012).

Unfreezing is the first step in the process of changing behavior from a status quo or letting go of old behaviors (Kritsonis, 2005). This stage is the most complex stage of the process due to the normal resistance of the people to change (Lewin, 2012). This project involved the nursing staff. Careful preparation was established. Preparation included creating a vision for change that employees can relate to, communicating the vision clearly and effectively, developing a sense of urgency and the need for change, and supporting and allowing them to actively participate in the process (Lewin, 2012). The vision was the reduction of hospital- 
acquired pressure injury through a set of clinical practices (bundle). The HAPI data presented is factual and is currently an existing problem in the hospital. The evidence-based intervention was presented, and educational action plan was explained to the staff. Educational need analysis was conducted as preparation before the education of HAPI prevention. Leadership support was part of the planning. Support was evident by approved staffing, funding, education, and training of staff. Motivating staff that the change is necessary, valid, and lead to the best outcome, established a trusting relationship for the need to change (Kritsonis, 2005).

Lewin's second stage, the actual change process, is when the people are confronted with implementing the new innovations/interventions/systems (Lewin, 2012). The bundle implementation was the intervention for this project. The implementation of the new bundle interventions needed the full support of the senior leadership in terms of staffing needs, technology, and financial cost. It is through the full support of the administrative team as evidenced by their commitment to the project and eliminating obstacles, that the staff felt comfortable and safe in participating and actively involving in the process. It is in this change stage that the changing of thought, feelings, behaviors, or all three, leads to a more productive functioning (Kritsonis, 2005).

The final stage is refreezing/the freezing stage. After the change has been implemented within the system, it must be a part of the organization's culture for it to be successful and sustained. The protocols developed with the bundles became the standard clinical practice for this project. These new thought processes, practices, and behaviors adopted during the transition became the routine. The outcome published by sharing results to whole organization, which is the reduction in HAPI. This is also the time when positive feedback, encouragement, recognition, and rewards are given to nurture positive feelings amongst the staff who actively 
participated in the project. This is where the change is now their new habit and standard.

\section{Plan-Do-Study-Act Model}

The PDSA model was used in addition to Lewin's theory of change for this project. This model was used to plan and implement this change project (IHI, 2019). The model of improvement framework has two parts: three fundamental questions, addressed in any order, and the PDSA cycle to test the change in a work setting (Institute for Healthcare Improvement, 2014). The three questions were the following:

1) What are we trying to accomplish? For this project, the first phase is the educational needs of the staff on skin and risk assessment, use of the Braden scale, identifying patients' risk for PI, and HAPI prevention. Once the educational needs were met, implementation of the interventions follow. The goal is the $15 \%$ reduction of HAPI in ICU.

2) How will we know if the change is an improvement? For this project, every phase was tested using the PDSA cycle. The PDSA cycle provides a means to test a change - by planning it, trying it, observing the results, and acting on what is learned.

3) What changes can we make that will result in improvement? With the PDSA cycle, the results of the analysis and evaluation determine if the different phases of the project showed improvement.

The PDSA model allowed the staff team to evaluate the success or failure of intervention and choose to adopt or reject the associated intervention and proceed to the next with each cycle (Provost, 2019). The model also offers accessibility, applicability, and simplicity for the staff with minimal quality improvement training or experience (DeOreo et al., 2012). The other part of the PDSA model is the actual P: plan, D: do, S: study, and A: act. 
Figure 1 shows the four steps of the PDSA model. In the Plan phase, this was the preimplementation phase for the project. This can also be any phase of the project. The Do phase is the action step where change takes place. This can include the implementation of new process, education, and training, and use of new equipment or supplies as part of the bundle. The Study phase includes data collection completed for each phase/process. Data collection can be for a specific process or the whole project. The data related to the process or the change project is evaluated. In this phase, it was determined what actions to be taken for the next phase or the next project. The Act step is the last phase where the project manager/leader with the team and administrative leadership decide what actions should be taken because of the change project. This phase is also applicable when deciding what actions to take from one phase to the other.

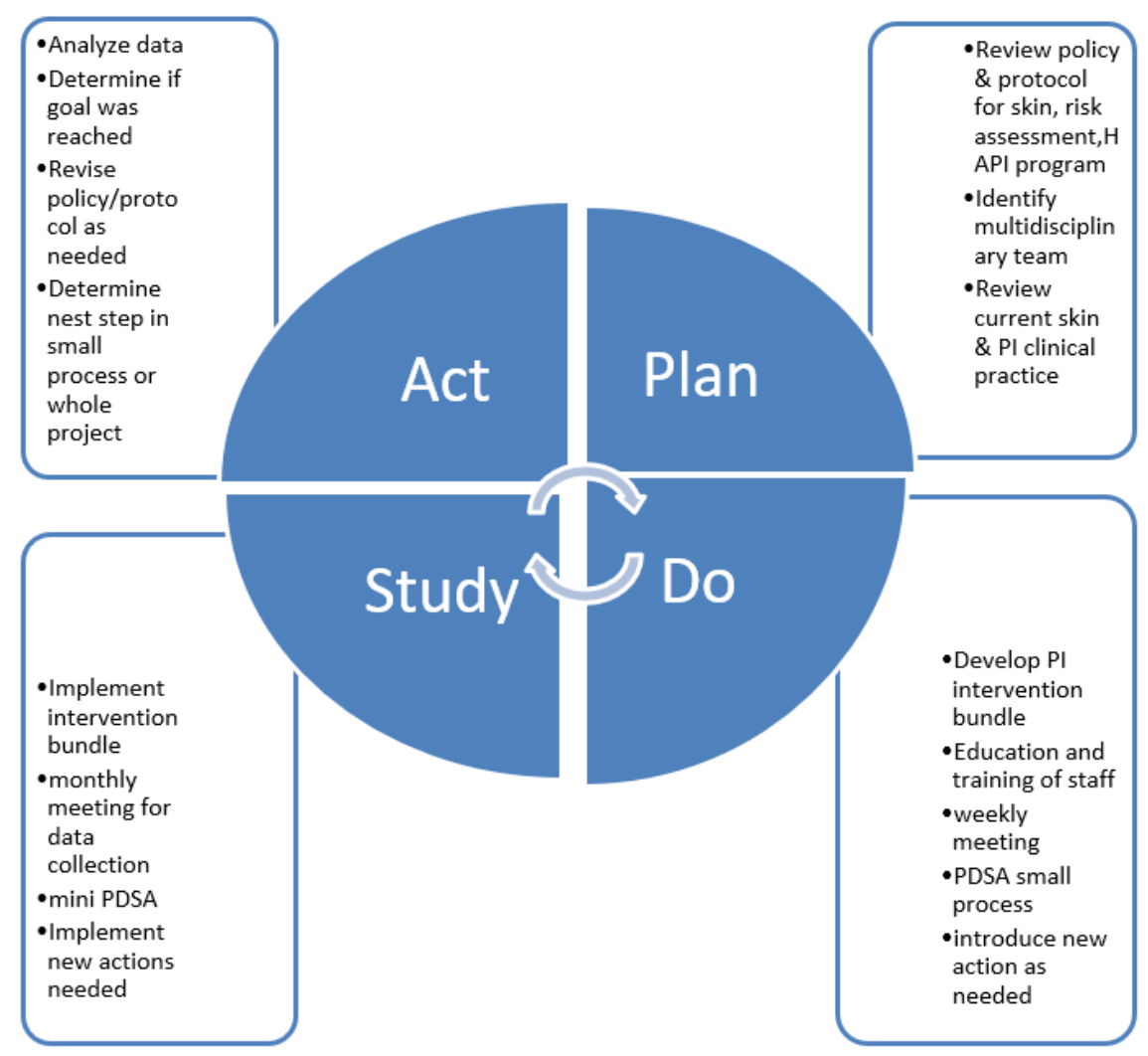

Figure 1. Plan-Do-Study-Act (PDSA) Model (IHI, 2019). 


\section{Synthesis of the Literature}

The reviewed literature supported evidence of effective use of a pressure injury preventive bundle in reducing the incidence of pressure injuries in an acute care setting (Amr, Yousef, Amirah, \& Alkurdi, 2017; Anderson et al., 2015; Coyer et al., 2015; Roberts et al., 2016; Tayyib \& Coyer, 2016; Tayyib, Coyer, \& Lewis, 2016). Seven articles met the inclusion criteria and were used for this literature review. As shown in Figure 2, the breakdown of articles includes a randomized control trial (RCT) $(n=2)$, qualitative descriptive studies $(n=1)$, pre and post study design ( $n=2)$, Quasi-experimental pre and post interventional research $(n=1)$, and observational prospective study design ( $n=1)$. A literature synthesis of these articles included: 1$)$ in-patient status characteristics and risk factors for pressure injury development, 2) current recommendations for pressure injury prevention, and 3) other interventions to reduce HAPI incidence. Refer to Figure 2 for the PRISMA flow diagram. 


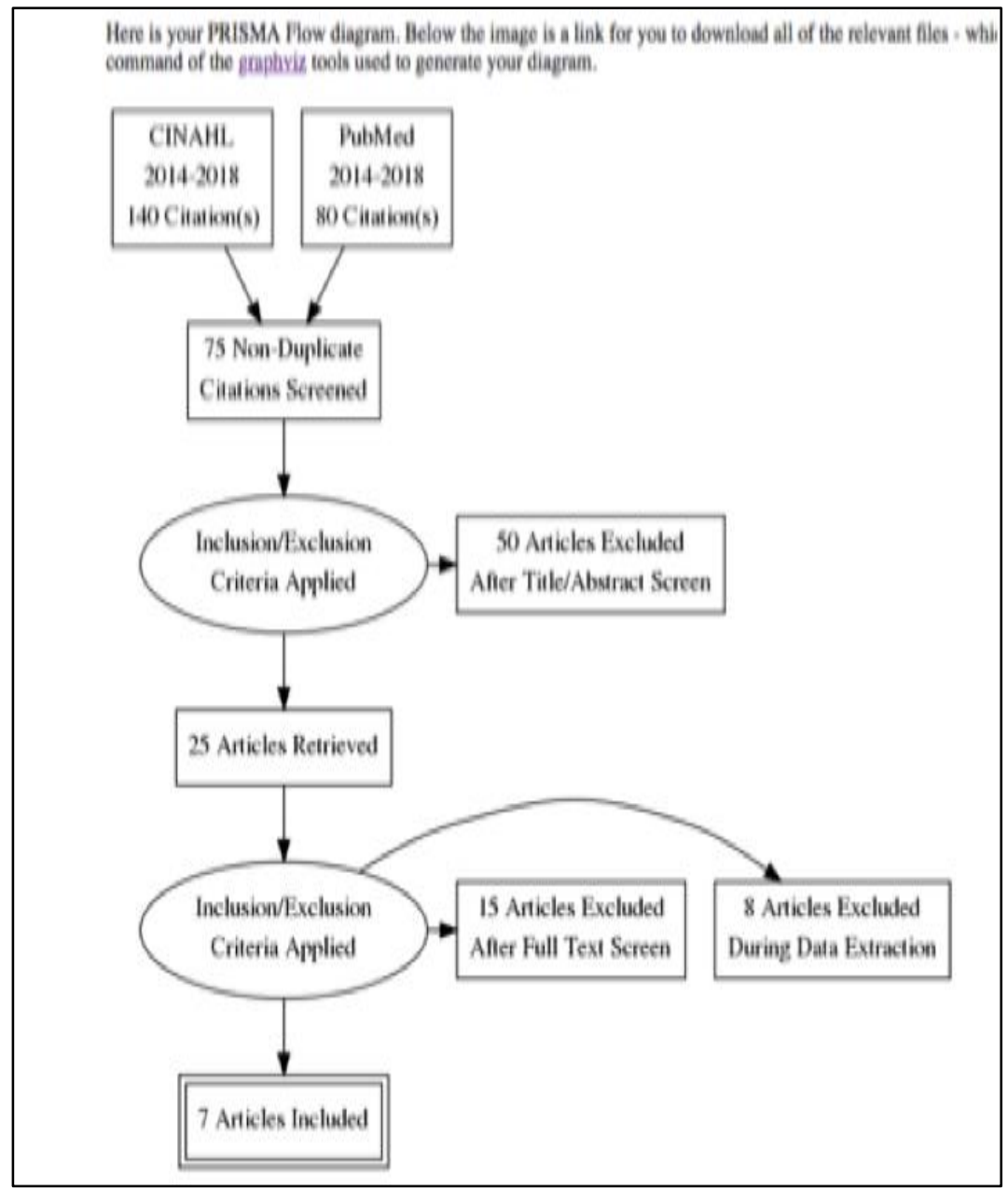

Figure 2. PRISMA flow diagram.

The PI bundle implementation is effective in reducing the incidence of pressure injuries as supported by several research and studies. The term bundle refers to a set of three to six evidence-based interventions implemented as clinical practice to improve patient outcomes (Horner \& Bellany, 2012; Tayyib, Coyer, \& Lewis, 2015). A bundle approach is more effective than clinical guidelines due to a mandatory and process-oriented nature (Chaboyer et al., 2016; Gill, 2015; Robb et al., 2010; Tayyib et al., 2015). The identification of patients at risk for development of HAPI is an important prevention initiative. Several assessment tools have been designed and tested to identify patients at risk for PI (Braden \& Bergstrom, 1989; Norton, McClaren, \& Exton-Smith, 1962; Waterlow, 1987). A literature review conducted by McGough, 
(1999) reported over 40 different pressure injury prevention assessment tools and concluded that none of these tools were consistently reliable for all clinical situations, as different patient groups have different clinical needs, and PI prevention tools should be used in the appropriate clinical setting. One of the most accepted pressure risk assessment tools that has been shown to have the best reliability and validity indicators in various healthcare settings, is the Braden scale, which produces a PI score based on known risk factors (Braden \& Bergstrom, 1989; Braden Scale, 2016). Refer to Appendix B.

\section{Practice Recommendations}

The evidence review supported the implementation of bundle interventions to reduce the incidence of pressure injury in acute care settings. The Hospital Acquired Pressure Ulcers/Injuries Change Packet was developed by Health Research \& Educational Trust (HRET) was used as an intervention bundle. The HRET change packet was the summary of themes from high performing health organizations nationwide (HRET, 2017). The HRET was developed through the sharing of evidence-based clinical practices, site visits, and subject matter expert's contributions. There are four major guideline components: 1) primary drivers, 2) secondary drivers, 3) change ideas, and 4) process measures. The five primary drivers were as follows: 1) conduct skin and risk assessment, 2) manage moisture, 3) optimize nutrition and hydration, 4) minimize pressure, shear, and friction, and 5) education and training of staff. The change ideas were specific to the identified needs of the unit. The ICU/MICU benefited from the preventive pressure injury bundle implementation. The monitoring, auditing, and feedback to stakeholders was a continuous process to ensure staff compliance of the bundle interventions. 


\section{Project Setting}

The setting for this project was a 530-bed hospital in South Texas. This hospital is located near the border of Mexico, thereby serving mostly Hispanic population. This is a fullservice, for-profit hospital with a functioning Level 1 ER trauma, with neonatal, pediatric, as well as adult critical care services. Other services are available such as women's services, rehab, behavioral health, and medical-surgical departments. The hospital also has wound care services, cancer treatment services, cardiac catheterization laboratory, perioperative services, and imaging services. This hospital is also affiliated with the graduate medical education (GME) program; therefore, it is also a teaching hospital.

The ICU/MICU is a combined 31-bed capacity, critical care unit within this 530-bed acute care facility. These two critical care units provide highly skilled critical care for adult trauma, cardiovascular patients, medical-surgical patients, neurological patients, and other critical conditions requiring intensive care services (DHRHealth, 2019). The critical/clinical care providers include Adult Critical Care Intensivist, Pulmonologist, Neurologist, Neurosurgeon, General, Trauma, Cardiovascular, Thoracic Surgeons, Critical Care Physician Assistants, Critical Care Nurse Practitioners, Critical Care Nurses, Pharmacist, Physical Therapist, Occupational Therapist, Respiratory Therapist, Nutritionist/Dietitians, Case Managers, Certified Nursing Assistants, and other allied care staff.

The nursing staffing matrix in the ICU/MICU is 1:2 and is adjusted based on patient acuity. Maintaining the standard ratio of nurse to a patient allows the nursing staff to implement preventive measures like HAPI prevention interventions. The additional certified nursing staff is vital to assisting nurses with other patient needs like personal care and other non-licensed responsibilities. 
An increase in the incidence of HAPIs hospital-wide attracted the nursing staff as well as the senior leadership's attention. The need for evidence-based clinical practices in preventing HAPI was apparent. An organizational need for PI assessment was conducted and the data supported the need for the EBP project. The stakeholders identified were the nursing leadership, that is the Chief Nurse Executive, Nursing Directors, Nursing staff, Physicians, Intensivist, Therapist, Dietitian, Senior Leadership, Board Members, Wound Care Physicians and Nurses, Nursing Assistants, patients, and their families.

The sustainability plan included an active multidisciplinary team that conducted continuous monitoring. The team consisted of an ICU RN champion, HAPI Bundle Intervention champions (charge nurses for both shifts, staff nurses for both shifts, wound care nurses, physical therapists, occupational therapists, respiratory therapists, and a dietitian). Continuous monitoring included auditing, ongoing organizational and nursing leadership support, constructive feedback, updates to key stakeholders, recognizing and rewarding staff for compliance, and successes. Incorporating the bundle interventions into the EHR workflow was vital. New HAPI policy review and continuous education were important, especially with new staff onboarding.

An organizational Strength, Weakness, Opportunity, and Threat (SWOT) analysis was performed with the team. As shown in Figure 3, the strengths identified were HAPI data that supports the need for the project, executive and nursing leadership support, multidisciplinary team, and support from quality, safety, and risk management department leadership. The weaknesses were inconsistent skin assessment on admission, the inconsistent risk for PI assessment, and limited PI education and training. Opportunities were to review, and revise policies related to PI prevention, need for physician champion, need for nursing champions, implement PDSA cycle. The threats identified were a reputational threat, patient dissatisfaction, 
potential litigation, potential reimbursement loss, a potential increase in cost both to patient and organization.

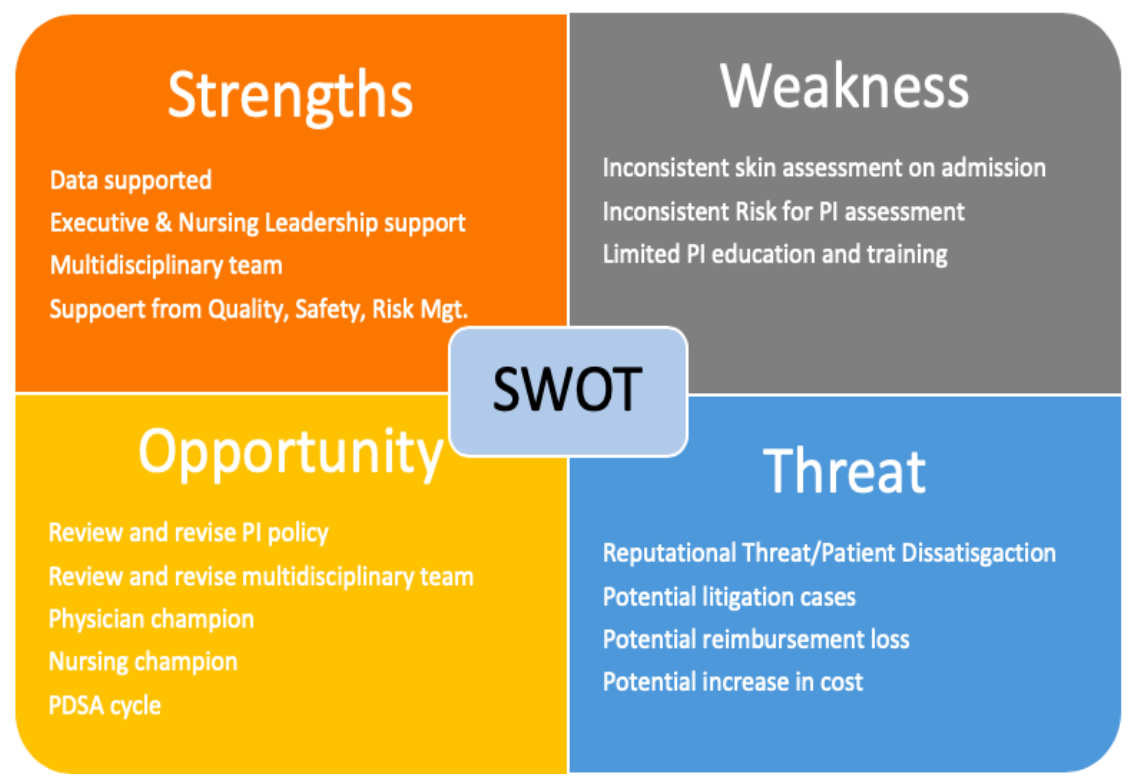

Figure 3. SWOT analysis.

\section{Project Vision, Mission, Objectives}

The EBP project vision was to improve pressure injury outcomes in adult patients in the ICU/MICU. The vision is consistent with the organization's high-quality and safe care for all patients admitted by equipping staff with skills, knowledge, technological innovations, and by promoting collaborative, integrated, and excellent care. The mission of the project is to reduce the incidence of pressure injury and is in alignment with organization's mission of commitment to quality and safe patient-centered care, for every patient, with every encounter (DHRHealth, 2019).

The short-term goals for the EBP project included a $15 \%$ or more reduction in the incidence of PIs. 90\% or higher staff compliance with HAPI education in three months. The long-term goals are a reduction of $75 \%$ or more in the incidence of PIs, the mitigation of risks to avoid staff non-compliance, to ensure a sustained reduction in pressure PIs incidence and to roll 
out the HAPI program to the rest of the in-patient departments.

\section{Project Description}

The IHI's model of improvement framework was applicable for this change project and served as our guide for any system-level change (IHI, 2019). Associates in process improvement developed the framework in 1990 and structured as an algorithm to achieve improvement goals through learned experience and intentional action (Langley, Nolan, Nolan, Norman, \& Provost, 2009). The three questions that guided this model are the following:

1) What are we trying to accomplish?

The first phase of this project was the education and training of the staff on skin and risk assessment, the Braden scale, identifying patients' risk for PI, and HAPI prevention interventions. Implementation of the HAPI interventions started after staff education. The result of data revealed no reduction in the incidence of HAPI but a decrease in the severity of the pressure injury from Stage Two to Stage One.

2) How will we know if the change is an improvement? Continuous monitoring and auditing of the implementation took place during every phase and was tested using the PDSA cycle. The PDSA cycle provided a means to test a change - by planning it, trying it, observing the results, and acting on what was learned.

3) What changes can we make that will result in improvement? With the PDSA cycle, the results of the analysis and evaluation determined if the different phases of the project showed improvement.

The steps of the Model of Improvement (IHI, 2019) were followed consisting of forming the team; setting aims; establishing measures; selecting changes; testing the changes; implementing the changes; and spreading the changes. The steps in this model were vital in the 
completion of the project.

\section{Forming the Team}

A committed and dedicated multidisciplinary team including the ICU/MICU bundle champions was formed before the implementation process. The Project Manager (DNP student) led the team with the active participation and leadership of the ICU/MICU Clinical Coordinator. The other members were the Stryker Educator, Wound Care Director, Nursing Educator, and ICU/MICU charge nurse. The Dietitian was consulted as needed. There was no Physician Champion as planned due to the change in the medical staff leadership role. The initial meeting was scheduled to discuss phases and timeline and the roles and responsibilities of each member. An ongoing meeting was also scheduled for updates.

\section{Setting Aims}

Describing a specific time frame to measure the achievement of a specific outcome and process measures was the focus of this step in the model. The project timeline was vital to achieving the goals of the project. The timeline included specific tasks, assigned personnel, and time frames for each task. The project timeline started with securing IRB approval from the University and the Organization. The IRB approval (Appendix A) from the University and the organization were completed, and the first phase of the project was about to be implemented but due to the COVID-19 pandemic, the project was put on hold. until the restrictions lifted. At the beginning of summer 2020, the implementation phase was resumed. The HAPI interventions started with staff education and training. Implementation of the HAPI interventions was reduced to 3-weeks from June 1-21, 2020. Data collection was completed on July 3, 2020. The DNP student consulted with the Organization's Clinical Research Scientist to assist with data analysis. 


\section{Establishing Measures}

The DNP student presented to the multidisciplinary team the specific outcome measures and process measures to identify areas for improvement. To signify improvement, a $90 \%$ compliance of HAPI prevention education and training was achieved. There was no reduction in the number of pressure injury incidence, but the result showed a decrease in the severity of pressure injury from Stage Two to Stage One. Continuous monitoring, audit, and constructive feedback were done by the ICU champions and the DNP student to ensure compliance with the HAPI interventions.

\section{Selecting Changes}

The change project was focused on the reduction of incidence of PIs through staff education and training on the HAPI prevention program and the implementation of the HAPI interventions.

\section{Testing Changes}

The PDSA cycle was used to evaluate the effect of the HAPI interventions in reducing the incidence of PIs in ICU/MICU. Continuous monitoring of compliance of the HAPI interventions was performed and feedback and updates communicated to the ICU/MICU staff.

\section{Implementing Changes}

The implementation of the HAPI prevention program in the ICU/MICU adult patients required a budget that included staffing, supplies, and financial cost. The staffing included the ratio, education, and training. The supplies included equipment and other material resources included in the HAPI program. The financial cost included the salary of staff, equipment, supplies, and other resources in the preventive program. See Appendix D for the EBP project budget. 


\section{Spreading Changes}

The EBP project outcome was reviewed with the project team and nursing leadership. A PowerPoint presentation was limited to nursing directors and nursing leadership due to COVID19 restrictions. The organization's priority at this time was focused on COVID-19 units and staffing. The hospital was experiencing a sudden rise in COVID-19 patients' admission and staffing. The use of posters, PowerPoint presentation, short 10-15 minutes meetings with ICU/MICU remained as plans for dissemination. With the approval of the administration and when the situation allows, other areas in the organization may be included in the presentation. The DNP student continues to share these results through a newsletter, grand rounds, and department meetings. Regional and national conferences as a poster presentation is another option for sharing the results. See Appendix C for Project Schedule and Appendix D for the budget.

\section{Project Evaluation and Data Analysis}

The PICOT question for this change project was: In the Intensive Care Unit/Medical Intensive Care Unit (ICU/MICU) patients aged 18 and older [P], does a pressure preventive bundle $[\mathrm{I}]$, compared to routine pressure injury care $[\mathrm{C}]$, reduce the incidence of pressure injury [O], within 21 days? [T]. The evaluation process is vital in any change project as this phase involves identifying, monitoring, and measuring the outcomes and goals to reach success upon project completion. Planning and project management minimized and controlled unrelated variables. Auditing, monitoring, and providing feedback and staff support ensured that the independent variable of implementing preventive pressure injury interventions in the ICU/MICU patients resulted in a decrease in the severity of pressure injury. 


\section{Data Collection}

Sample. The DNP project manager reviewed daily admissions in the ICU/MICU and selected the participants that met the following criteria: adult patients over 18 years old, a Braden score of 18 and below, no pressure injury on admission, and admitted from January 1-21, 2020. A total of 90 participants were selected and were tracked until they were transferred to another unit within the hospital, to another facility, is discharged or dies. Demographic data were collected that included age, gender, admitting diagnosis, admitting diagnosis, Body Mass Index (BMI), Braden score, and length of stay (LOS) in ICU/MICU. Data were organized and presented utilizing frequency and percentage distribution figures.

Figure 4 contains the frequency and percentage distribution of participants by age group. The total number of participants was also included in the figure. The green bars signify frequency and the blue bars signify percentage. The mean, median, and standard deviation were calculated based on the participant's age group. As presented in figure 4, two (2\%) participants belonged to the 22-34 age group, six (7\%) participants belonged to the 35-47 age group, 22 (24\%) participants belonged to the 48-60 age group, 38 (42\%) participants belonged to the 61-73 age group, $16(18 \%)$ participants belonged to the 74-86 age group and six (7\%) participants belonged to the 87-99 age group. The youngest participant was 22 years old and the oldest was 94 years old. There was a total of 90 participants. The calculated mean age was 64.9 , the median was 65.5 , and the standard deviation was 14 . 


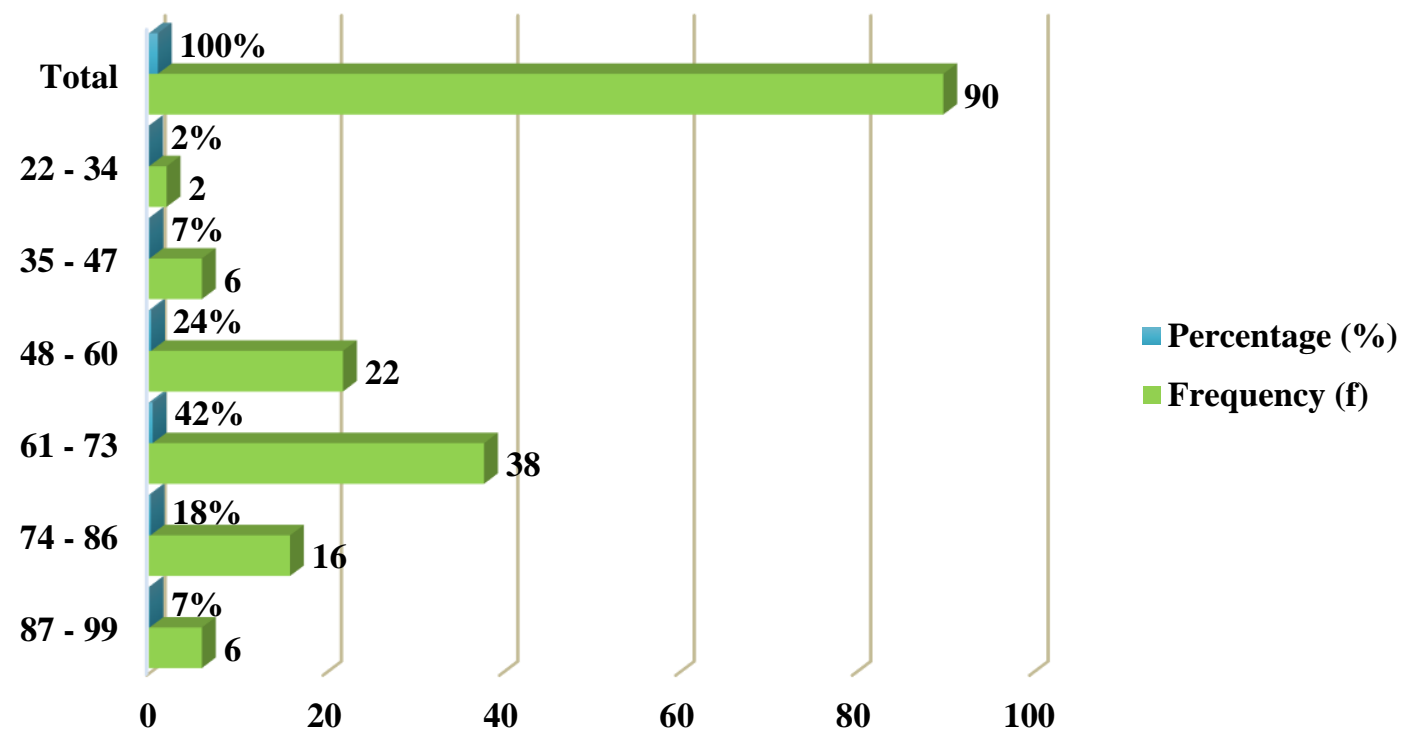

Figure 4. Frequency and percentage distribution of participants by age group

Figure 5 shows the participants' frequency and percentage distribution by gender. Each participant was categorized as either male or female. The total number of participants was also included in the table. The green bars indicate the frequency and blue bars indicate the percentage. As shown in figure 5, $52(58 \%)$ participants were male and 38 (42\%) participants were female. There were 90 participants.

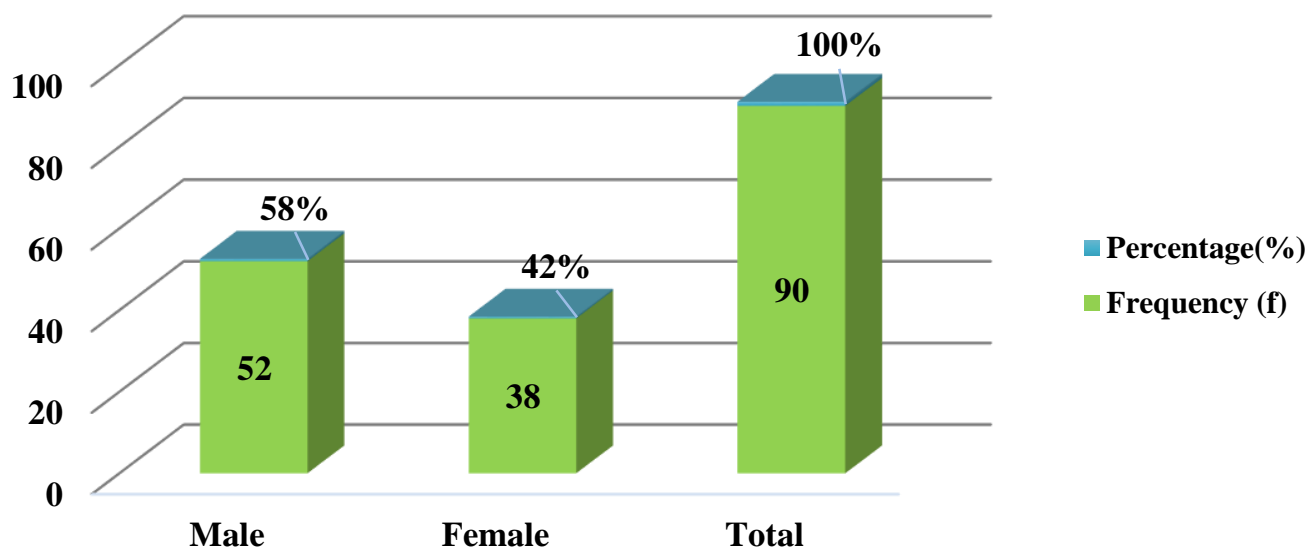

Figure 5. Frequency and percentage distribution of participants by gender 
Figure 6 shows the frequency and percentage distribution of participants by BMI. Participants were classified as underweight, normal, overweight, or obese. The green bars represent frequency and the blue bars represent the percentage of the overall group of 90 participants. The mean, median, and standard deviation were calculated based on the participants' BMI collected. As shown in figure 6, one (1\%) participant was categorized as underweight, 18 (20\%) participants categorized as normal, 19 (21\%) participants were categorized as overweight, $47(52 \%)$ participants were categorized as obese, and five (6\%) participants did not have BMI documented. Actual BMI showed that the lowest BMI was 17.7 and the highest BMI was 60.8 from the total of 90 participants. The calculated mean was 34.95 , median of 31.2, and standard deviation was 30.45 .

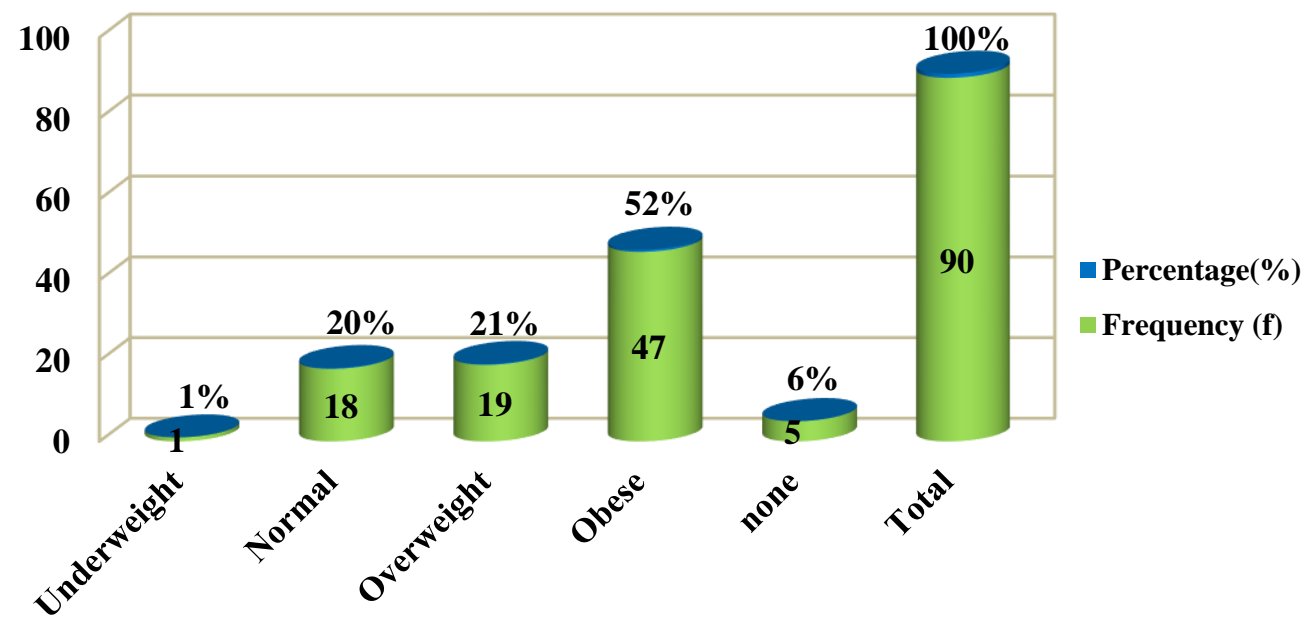

Figure 6. Frequency and percentage distribution of participants by BMI group

Figure 7 presents the participants distribution according to their admitting diagnosis in the ICU/MICU. As indicated in figure 7, 38 (42\%) participants were admitted with cardiovascular system conditions, two (2\%) participants were admitted with cirrhosis of the liver, one $(1 \%)$ participant was admitted with colon cancer, one $(1 \%)$ participant admitted with 
Diabetic Mellitus Type II (DM2), two (2\%) participants admitted with endocrine system conditions, nine (10\%) participants were admitted with gastrointestinal system conditions, eight (9\%) participants were admitted with genitourinary conditions, one (1\%) participant was admitted with musculoskeletal conditions, three (3\%) participants were admitted with neurological conditions, one (1\%) participant was admitted with respiratory failure, 17 (19\%) participants were admitted with respiratory system conditions, four (5\%) participants were admitted with sepsis, and three (3\%) participants were admitted with severe sepsis.

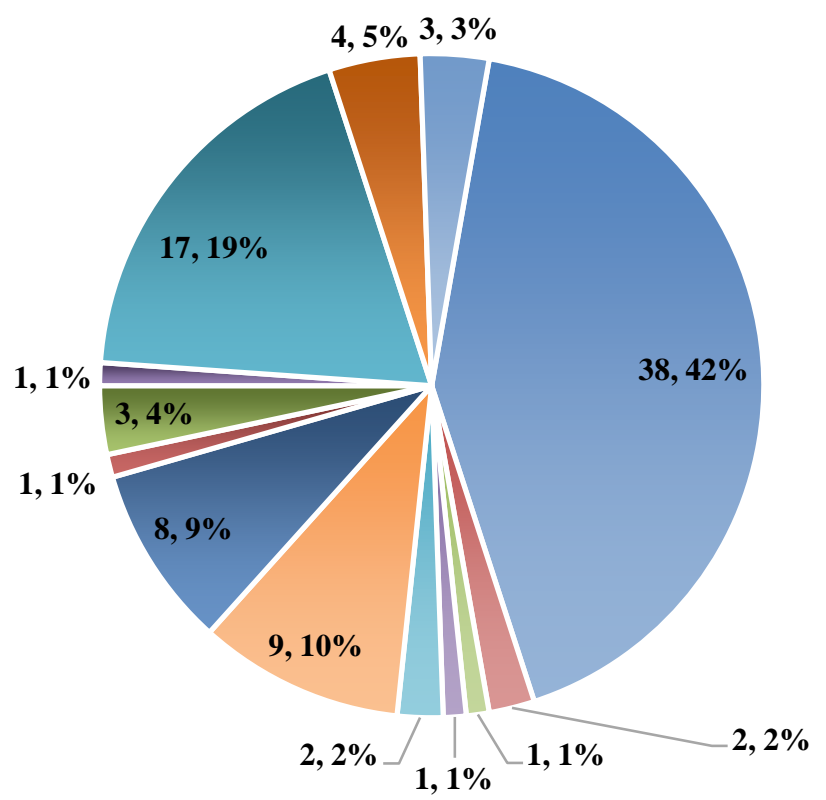

- Cardiovascular System

- Cirrhosis of Liver

- Colon Ca

- DM2

- Endocrine System

- Gastrointestinal System

- Genitourinary System

- Musculoskeletal System

- Neurological System

- Respiratory Failure

- Respiratory System

- Sepsis

- Severe Sepsis

Figure 7. Frequency and percentage distribution of participants by diagnosis group

Figure 8 reveals the frequency and percentage distribution by participants' length of stay (LOS). The length of stay starts from admission and ends when the participant is discharged home, transferred to another unit within the hospital, transferred to another facility, or dies. Green bars indicate the frequency and blue bars indicate a percentage. As described in figure 8, $21(23 \%)$ participants had one day LOS, 20 (22\%) participants had two days LOS, 18 (20\%) participants had three days LOS, 13 (14\%) participants had four days LOS, 10 (11\%) participants 
had five days LOS, five (6\%) participants had six days LOS, and three (3\%) participants had seven days LOS. The calculated mean was 2.98 , the median was 3 , with a standard deviation of 1.68 .

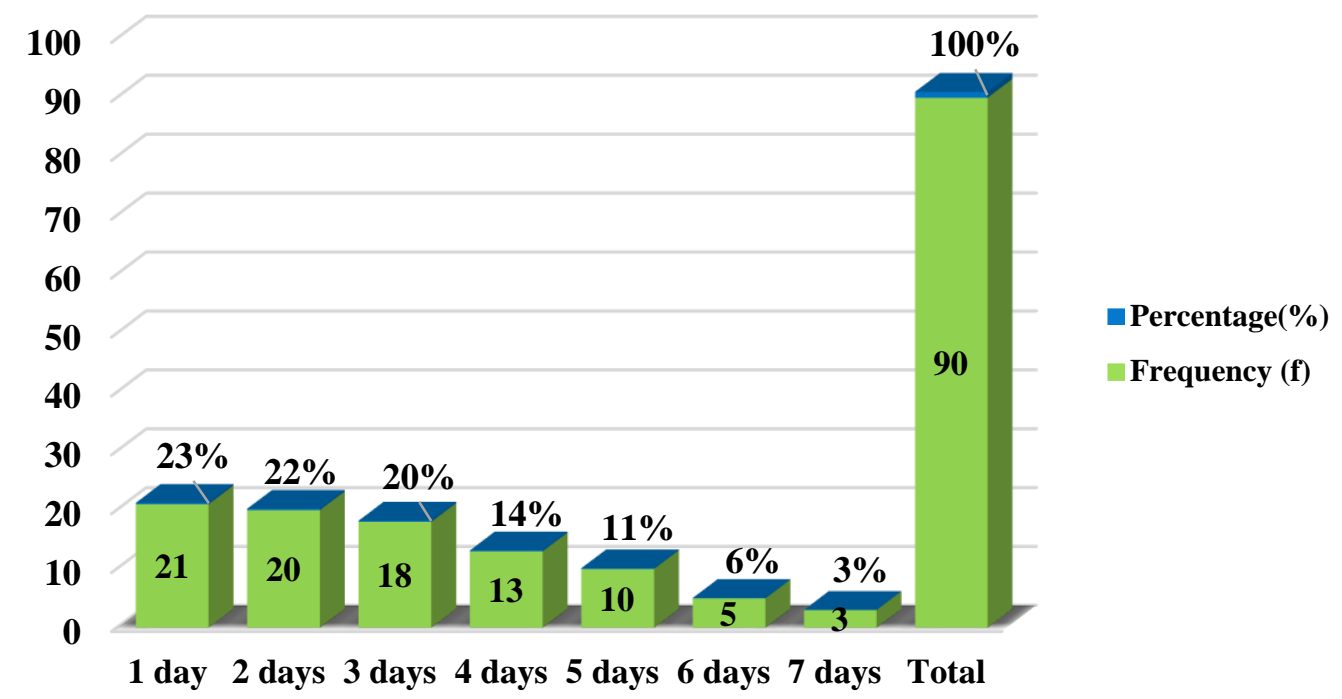

Figure 8. Frequency and percentage distribution of participants by length of stay (LOS)

Figure 9 describes the stages of PIs observed at baseline in March 2020 and postimplementation in June 2020. The green bars signify baseline data, and blue bars indicate stages of PI in June 2020. Data at baseline were compared to data collected post PIPBI intervention. As described in figure 9, the total baseline PIs were five: four Stage Two, and one DTI. The post-implementation data collected in June 2020 showed six Stage One pressure injuries. There was an increase in the incidence of pressure injury but a decrease in the severity of PIs. There were no Stage Three and Stage Four PIs developed post-implementation. There is no statistical test that compares simple numbers, which is number five and number six. These numbers can be given a score of severity. The four pressure injuries Stage Two can add up to equals eight and the six injuries Stage One can add up to eight. This accounts for both numbers representing the 
number of pressure injuries and severity that is the stages. A decrease from eight to six is a $25 \%$ improvement.

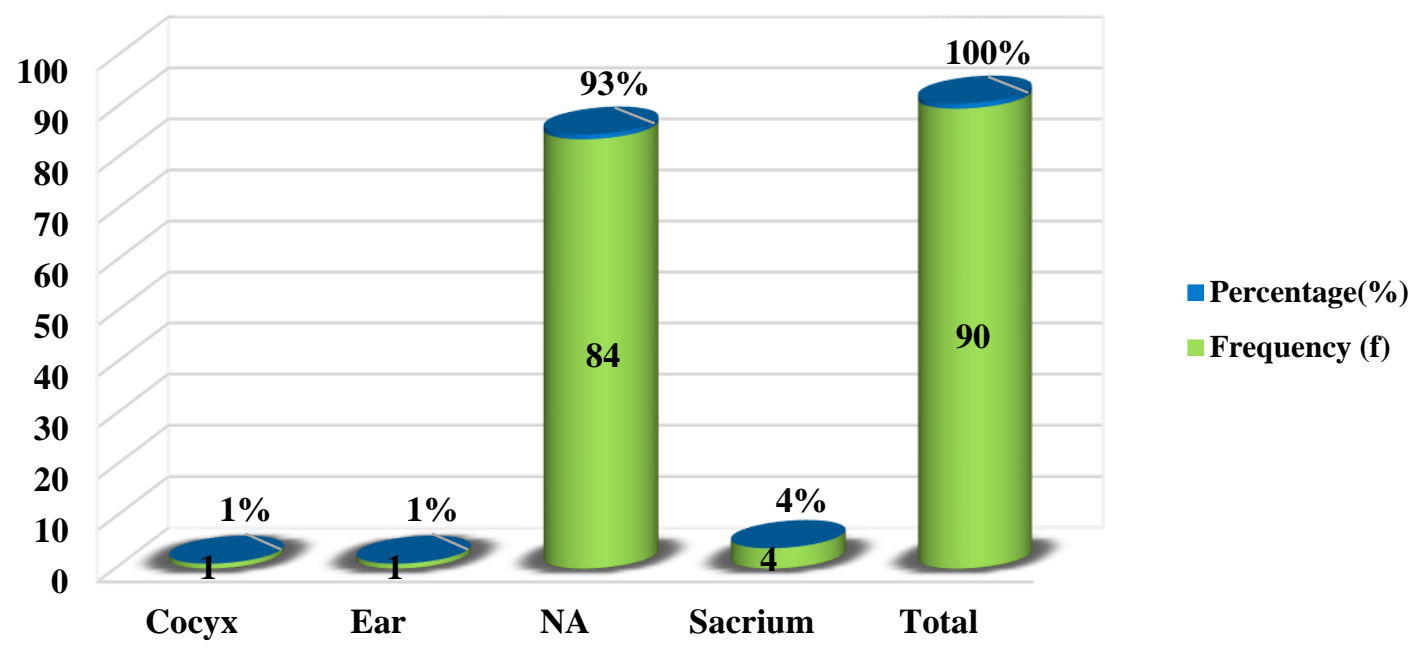

Figure 9. Stages of PIs observed at baseline (March 2020) and post implementation (June 2020)

As described in figure 10, there were four HAPIs Stage Two and one DTI in March 2020 pre- implementation of bundle interventions, and there was a total of six Stage One postimplementation of bundle intervention in June 2020.

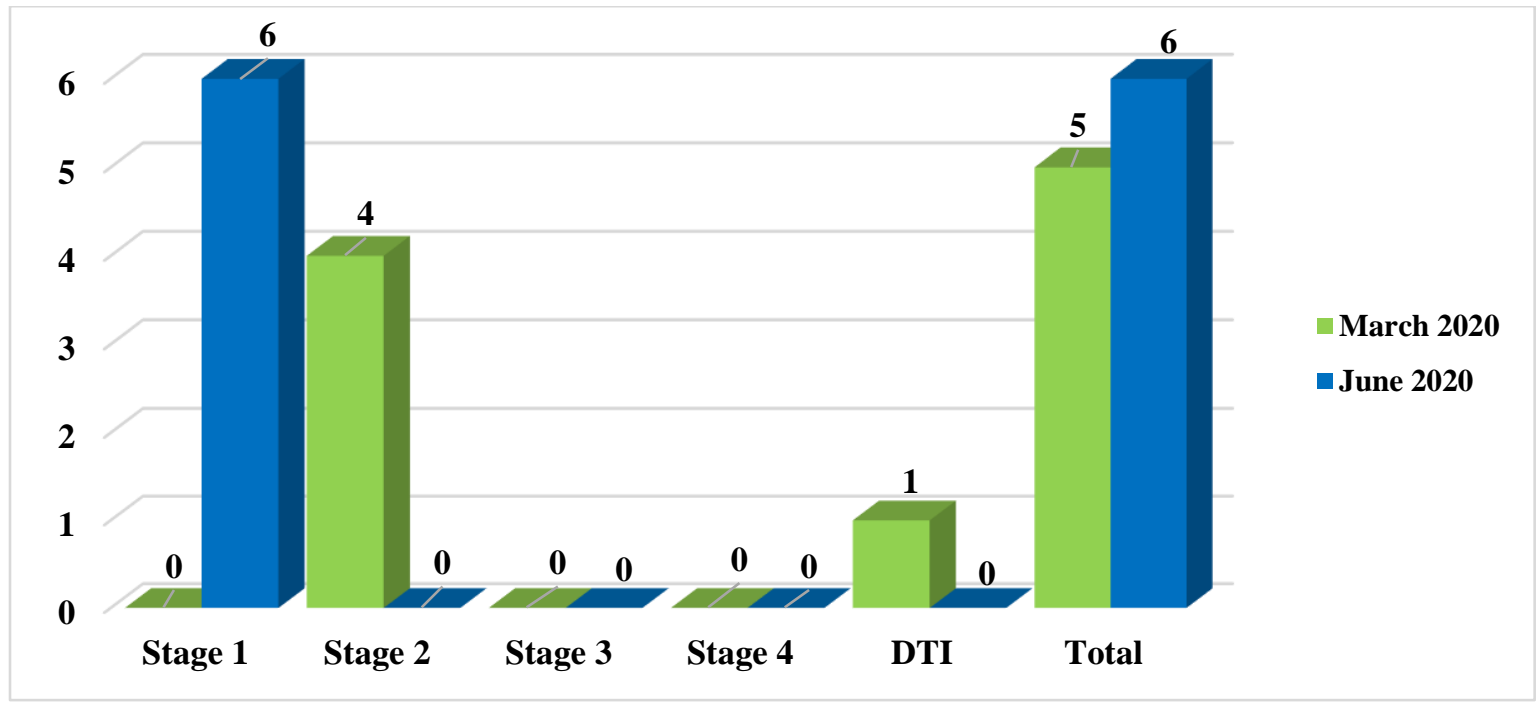

Figure 10. Stages of PIs in March 2020 and June 2020 
As shown in Table 1, a paired-samples $t$-test was conducted to compare the results of the first Braden score on initial assessment and the last Braden score on discharge postimplementation of bundle interventions. There was a significant difference in the first Braden scores on assessment as shown in the calculated mean of 14.44 and standard deviation of 2.22 compared to the Braden score on discharge with the calculated mean of 16.40 and standard deviation of 3.35. Based on this result there is a difference in the Braden score post interventions as shown in the result of the $t$-value of 5.928 at alpha $=.05$. This proves that the bundle implementation was effective.

Table 1

First and Last Braden Paired Samples

\begin{tabular}{ccccccc}
\hline Variables & $N$ & Mean & SD & Df & $t$ & $p$ \\
\hline First Braden & 90 & 14.44 & 2.22 & 89 & 5.928 & 0.000 \\
Last Braden & 90 & 16.40 & 3.35 & & & \\
\hline
\end{tabular}

Formative evaluation. The primary outcome measure is a $15 \%$ reduction or more in the incidence of Hospital-Acquired Pressure Injuries (HAPIs) and a secondary outcome measure of reducing the severity of Pressure Injuries (PIs) developed after a 3-week implementation of the PIPBI intervention. The incidence rate refers to the total number of a new case of PIs in the adult ICU/MICU patients at a given time multiplied by 100 and divided by the total number of ICU patients in the same given time. The incidence is a valid and feasible measurement of the effectiveness of pressure injury prevention strategies (Gill, 2015). 
The EBP project manager conducted the data collection for the primary outcome measures for the 7-days, 14-days, and 21-days post-implementation. The post-implementation data collected were compared to the baseline data collected in March 2020. The severity of the newly developed PIs was classified as Stage One, Two, Three, and Four, unstageable, deep tissue injuries, and medical-related pressure injury as defined by the European Pressure Ulcer Advisory Panel and National Pressure Ulcer Panel (2009).

The pre-implementation meeting was with the Project team consisting of the ICU/MICU Clinical Coordinator, the CNO, Educators, and the Wound Care Director. The meeting was a brief description and scope of the change project, the timeline, and the roles and responsibilities of each member. Education and training were initiated through staff meetings and one on one with the staff. After $90 \%$ RN compliance with education and training of the HAPI prevention program, implementation started. In the first week of the implementation phase, the team was able to rounds in the ICU/MICU both during the day and night shift and gave constructive feedback to the staff. The 7-days, 14-days was uneventful. Towards the middle of the 21-days of implementation, our organization suddenly shifted its focus on COVID-19 challenges due to an increase in the COVID-19 admissions. The 21-days implementation period was completed successfully.

The project's process measures are the staff compliance of the preventive bundle interventions. The project's goal of $90 \%$ or higher compliance with the implementation of the bundle interventions. Staff compliance was audited weekly to ensure treatment fidelity. The compliance audit was used to give staff positive feedback and an opportunity for any questions and or clarifications. 
The project's process measures were also the project's sustainability process. The ICU team need to continue with the auditing and monitoring the staff for compliance with the bundle interventions. Other sustainability measures included additional pressure injury documentation in the EHR, Education of the bundle interventions during general orientation for new nurses, annually for the regular staff and integrated into the yearly performance evaluation.

Balancing measures included education and training cost, cost of additional supplies, and equipment. For our organization, the supplies were approved as floor stock, therefore no additional cost added to the budget that needed approval. For this project, there was no additional cost for training as it was done during the regular staff meeting, and one on one done by myself. The financial measures are the total cost of treatment and the cost savings.

Summative evaluation. This change project's purpose was to evaluate the effectiveness of the preventive bundle interventions in reducing the incidence of HAPIs. A data collection form was adopted that addressed the participants' descriptive data that included admission date, age, gender, BMI, diagnosis, length of stay in ICU/MICU, Braden score, the incidence of PI with stage and location. The other data collection tool used was the compliance checklist. This checklist included RN documentation of skin and risk assessment once per shift, Braden score, and implementation of the bundle interventions. A compliance checklist is a tool used in auditing, monitoring as well as providing feedback to staff.

The primary outcome finding from the implementation of the intervention bundle did not show the reduction in the incidence of HAPI as intended; however, there was a reduction of the severity of pressure injury form Stage Two to Stage One. The staff showed compliance in the implementation of the interventions. The implementation period was shortened from a 12-week 
change project to a three-week project. There were some challenges to the implementation of the project due to the University of Saint Augustine student restrictions and the hospital restrictions.

The DNP student had to used other creative ways to start the project with virtual technology to schedule meetings. Communication was conducted via phone conversation/conference, emails, and text messages. Process measures for this EBP project consisted of staff compliance with the PIPBI intervention components. The bundle interventions included staff education and training, the skin assessment and risk assessment utilizing the Braden scale, managing moisture, optimizing nutrition and hydration, and minimizing pressure, shear, and friction. Staff compliance was audited seven, 14, and 21 days post-implementation to ensure fidelity and production of the desired outcome. Staff compliance was $90 \%$ and over with three out of the four bundle components. These results supported other literature reviewed. The shortened period of implementation of the project due to the COVID-19 restrictions, limited inperson feedback by the DNP project manager to the ICU staff. Most of the feedback was through the clinical coordinator via email. The reduction in the severity of the pressure injury postimplementation showed a positive outcome of the bundle interventions.

Limitations of this EBP project included a shortened implementation period from 12weeks to three weeks period. Despite the limited period, this still resulted in positive outcomes. The unexpected limitation was the pandemic COVID-19 restrictions. The pandemic changed the norm at work, at home, and in the community. The hospital's focus suddenly changed to the pandemic and affected all aspects of the research in the clinical setting. Fortunately, all the products needed for the interventions were approved and were made part of the supply and were utilized as planned.

The practice change is included in the revised policy and procedure. Education and 
training of the bundle interventions were made as part of the nursing orientation for the new employees and annually for the current employees. The lesson learned/take-home message is a readiness in any unforeseen challenges during the project implementation. Communication, integration of resources, an understanding of the project goals and outcomes, and leadership support resulted in a positive outcome.

\section{Dissemination of Project Results}

Dissemination is a significant process of translating the results of the project (White, Dusley-Brown, \& Terhaar, 2016). After the data collection and analysis, a PowerPoint presentation of the results and evaluation of the project was initially presented to the project team. The same PowerPoint presentation was sent to nursing leadership. Due to the present COVID-19 restrictions in the institution, an in-person presentation was not allowed therefore a virtual meeting was scheduled but eventually rescheduled to a later date. There were several meetings scheduled for poster presentations, panel discussions, and forums dependent on the hospital-wide restrictions and staff availability. Nursing staff, Medical students, GME residents, and any other clinicians are the intended audience. Flyers were produced and ready for distribution.

Coordination with marketing and information technology (IT) department was established to include flyers in the monthly newsletter. Handouts are available for distribution once the presentation is permitted. The DNP student planned to coordinate with the local and regional nursing organizations and the school of nursing programs for virtual presentation via online webinar meetings. The local organizations are more practical and convenient for the local and neighboring cities nurses. Some of these organizations offers continuing education units. An abstract was be submitted for review to these organizations. Further plans for dissemination 
include submission to a nursing journal. Guidelines for journal publication were obtained. The American Journal of Nursing (AJN) is the preferred journal for publication because of its reputation amongst nursing professionals, researchers, and educators. AJN publishes diverse nursing topics and the result for these pressure injury preventive interventions give the nursing industry the opportunity to be able to read, learn and adopt the processes into their own healthcare settings. To fulfill the DNP program requirements this paper was be submitted in full text to the SOAR@USA.SOAR@USA is an institutional repository that improves discoverability of this EBP project. This project's final paper was submitted to the Virginia Henderson Global Nursing e-Repository to facilitate worldwide dissemination of the DNP project information.

\section{Conclusion}

The purpose of this EBP project was to evaluate the effectiveness of the preventive bundle in reducing the incidence of HAPI. The anticipated result of the project was a $15 \%$ reduction in HAPI in ICU/MICU within the 3-weeks of bundle implementation. There was no decrease in the incidence of HAPI, but the result showed a decrease in the severity of the pressure injury from Stage Two pressure injury to Stage One pressure injury. Staff education, training, and skills check-off equipped the staff to adhere to the PI policies and protocol.

The project interventions raise staff awareness and ownership as observed by compliance with the implementation of bundled interventions. The vision and mission of the project aligned with the organization's vision and mission of innovations and positive outcome every encounter, every patient, every time. The decrease in pressure injury severity from five incidences of stage Two to six incidences of Stage One pressure injury saved the hospital \$ 30,000 just for this short period of project implementation. 


\section{References}

Amr, A., Yousef, A., Amirah, M., \& Alkurdi, M. (2017). A pre-post study evaluating the effectiveness of a new initiative, the PRESSURE Bundle, compared with standard care in reducing the incidence and prevalence of sacral pressure ulcers in critically ill patients in an intensive care unit in Riyadh, Saudi Arabia. Saudi Critical Care Journal, 1(3), 75-79. doi:10.4103/sccj.sccj_29_17

Anderson, M., Guthrie, P., Kraft, W., Reicks, P., Skay, C., \& Beal, A. L. (2015). Universal pressure ulcer prevention bundle with wound ostomy continence nurse (WOC). Journal of Wound, Ostomy, and Continence Nursing, 42(3), 217-225.

doi:10.1097/WON000000000000109

Armour-Burton, T., Fields, W., Outlaw, L., \& Deleon, E. (2013). The healthy skin project: Changing nursing practice to prevent and treat hospital-acquired pressure ulcers. Critical Care Nurse, 33(3), 32-40. doi:10.4037/ccn2013290

Braden, B., \& Bergstrom, N. (1989). Clinical utility of the Braden Score for predicting pressure sore risk. Advances in Skin \& Wound Care, 2(3), 44-51. Retrieved from https://pubmed.ncbi.nlm.nih.gov/2775473/

Braden Scale. (2016). Prevention plus: Home of the Braden Scale. Retrieved from http://www.bradenscale.com

Chaboyer, W., Bucknall, T., Webster, J., McInnesg, E., Gillespiea, B., Banks, M., ... Wallis, M. (2016). The effect of a patient centered care bundle intervention on pressure ulcer incidence (INTACT): A cluster randomized trial. International Journal of Nursing Studies, 64, 63-71. doi:10.1016/j.ijnurstu.2016.09.015 
Coyer, F., Gardner, A., Doubrovsky, A., Cole, R., Ryan, F. M., Allen, C., \& McNamara, G. (2015). Reducing pressure injuries in critically ill patients by using a patient skin integrity care bundle (INSPIRE). American Journal of Critical Care, 24(3), 199-209. doi:10.4037/ajcc2015930

DeOreo, P., Duval, L., Paul, R., Kodali, P., Rankin, L., Malony, D., ... Rosen, S. (2012). Medical director toolkit - ESRD Network Forum. Retrieved from http://esrdnetworks.org/resources/toolkits/mac-toolkits-1/medical-directortoolkit/medical-director-toolkit

DHRHealth. (2019). Services DHRHealth. Retrieved from www.dhrhealth.com

Edsberg, L. E., Black, J. M., Goldberg, M., McNichol, L., Moore, L., \& Sieggreen, M. (2016). Revised national pressure ulcer advisory panel pressure injury staging system. Journal of Wound, Ostomy, and Continence Nursing, 43(6), 585-597. doi:10.1097/WON.0000000000000281

Gill, E. (2015). Reducing hospital-acquired pressure ulcers in intensive care. British Medical Journal, 4(1), 2055-3015. doi:10.1136/bmiquality.u205599.w3015

Grealy, B., \& Chaboyer, W. (2012). Essential nursing care of the critically ill patient. In L. Aitken, A Marshall, \& W. Chaboyer (Eds), ACCCN's Critical Care Nursing, 131-163. Sydney, Australia: Elsevier Mosby.

Health Research \& Educational Trust. (2017). Hospital acquired pressure ulcers/injuries (HAPU/I). Chicago, IL: Health Research \& Educational Trust. Retrieved from http://www.hret-hiin.org/

Horner, D. L., \& Bellany, M. C. (2012). Care bundles in intensive care. Continuing Education in Anesthesia Critical Care \& Pain, 12(4), 199-202. doi:10.1093/bjaceaccp/mks021 
Institute for Healthcare Improvement [IHI]. (2014). The breakthrough series: IHIs collaborative model for achieving breakthrough improvement. IHI White Papers. Retrieved from http://www.ihi.org/resources/Pages/IHIWhitePapers/TheBreakthroughSeriesIHIsCollabor ativeModelforAchievingBreakthroughImprovement.aspx

Institute for Healthcare Improvement [IHI]. (2019). Science of improvement: How to improve. Retrieved from http://www.ihi.org/resources/Pages/HowtoImprove/ScienceofImprovementHowtoImprov e.aspx

Kritsonis, A. (2005). Comparison of change theories. International Journal of Scholarly Academic Intellectual Diversity, 8(1), 1-7.

Kruger, E., Pires, M., Ngann, Y., Sterling, M., \& Rubayi, S. (2013). Comprehensive management of pressure ulcers in spinal cord injury: Current concepts and future trends. Journal of Spinal Cord Medicine, 36(6), 572-585.

doi.org/10.1179/2045772313Y.0000000093

Langley, G. J., Nolan, K. M., Nolan, T., Norman, C., \& Provost, L. (2009). The improvement guide: A practical approach to enhancing organizational performance. San Francisco: Jossey-Bass.

Lewin, K. (2012). You cannot understand a system until you try to change it. Dorling Kindersley Ltd. Retrieved from http://search.ebscohost.com/login.aspx?direct=true\&db=edsgvr\&AN=edsgcl.2065800080 $\&$ site=eds-live

McGough, A. J. (1999). A systematic review of the effectiveness of risk assessment scales used in the prevention and management of pressure sores. MSc Thesis, University of York. 
National Pressure Ulcer Advisory Panel. (2014). NPUAP pressure ulcer stage/categories.

Retrieved from http://www.npuap.org/resources/educational-andclinical-resources/npuappressure-ulcer-stagescategories

Norton, D., McClaren, R., \& Exton-Smith, A. N. (1962). An investigation of geriatric nursing problems in hospital. London: Churchill Livingstone.

Ostadabbas, S., Yousefi, R., Nourani, M., Faezipour, M., Tamil, L., \& Pompeo, M. (2012). A resource-efficient planning for pressure ulcer prevention. NIEEE Transactions on Information Technology in BioMedicine, 16(6), 1265-1273.

doi:10.1109/TITB.2012.2214443

Provost, L. (2019). Quality improvement in healthcare: Five guiding principles. Retrieved from https://www.healthcatalyst.com/insights/quality-improvement-healthcare-5-guidingprinciples

Reilly, E., Karakousis, G., Schrag, S., \& Stawicki, S. P. (2007). Pressure ulcers in the intensive care unit: The forgotten enemy. Opus, 1(2),17-30. Retrieved from http://ferronfred.eu/onewebmedia/Pressure\%20ulcers\%20in\%20the\%20intensive\%20care \%20unit-the\%20forgotten\%20enemy.pdf

Robb, E., Jarman, B., Suntharalingam, G., Higgens, C., Tennant, R., \& Elcock, K. (2010). Quality improvement report using care bundles to reduce in-hospital mortality: Quantitative survey. British Medical Journal, 340(7751), 861-863. doi.org/10.1136/bmj.c1234

Roberts, S., McInnes, E., Wallis, M., Bucknall, T., Banks, M., \& Chaboyer, W. (2016). Nurses' perceptions of a pressure ulcer prevention care bundle: A qualitative descriptive study. BMC Nursing, 15(64), 1-10. doi:10.1186/s12912-016-0188-9 
Spetz, J., \& Brown, D. S. (2013). The value of reducing hospital-acquired pressure ulcer prevalence an illustrative analysis. The Journal of Nursing Administration, 43, 235-241. doi:10.1097/NNA.0b013e3182895a3c

Tayyib, N., \& Coyer, F. (2016). Effectiveness of pressure ulcer prevention strategies for adult patients in intensive care units: A systematic review. Worldviews on Evidence-Based Nursing, 13(6), 432-444. doi:10.1111/wvn.12177

Tayyib, N., Coyer, F., \& Lewis, P. A. (2015). A two-arm cluster randomized control trial to determine the effectiveness of a pressure ulcer prevention bundle for critically ill patients. Journal of Nursing Scholarship, 47(3), 237-247. doi:10.1111/jnu.12136

Tayyib, N., Coyer, F., \& Lewis, P. A. (2016). Implementing a pressure ulcer prevention bundle in an adult intensive care. Intensive and Critical Care Nursing, 37, 27-36. doi:10.1016/j.iccn.2016.04.005

Waterlow, J. (1987). Tissue viability: Calculating the risk. Nursing Times, 83(39),58-60. Retrieved from https://pubmed.ncbi.nlm.nih.gov/3684649/

White, K. M., Dusley-Brown, S., \& Terhaar, M. F. (2016). Translation of evidence into nursing and health care ( $2^{\text {nd }}$ ed.). New York, NY: Springer Publishing Company.

Zuo, X., \& Meng, F. (2015). A care bundle for pressure ulcer treatment in intensive care units. International Journal of Nursing Sciences, 2(4), 340-347. doi:10.1016/j.ijnss.2015.10.008 


\section{Appendix A: Approval Letters}

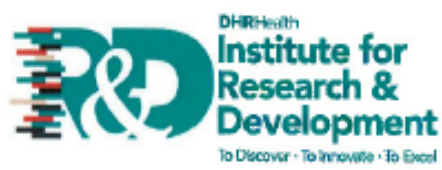

Date:

To:

$\mathrm{Cc}$ :

From

Subject:
March 5, 2020

Marisa Raynaldo

Mahesh Changlani, MD; Chairman

DHR Health Institute for Research and Development Institutional Review Board Committee

Quality Improvement Project Review Approval Letter

IRBNet ID: 1565931-1

Title: Implementation of Hospital-Acquired Pressure Injury (HAPI) Prevention Program

Dear Marisa Raynaldo,

We are pleased to inform you that your study has been reviewed by the office of the DHR Health Institute for Research and Development Institutional Review Board and has been determined to be a Quality Improvement project and not a human subject research project under 45 CFR 46 or 21 CFR 50, 56.

This is an official communication that notifies you that you may begin your project. Please keep this for your records.

Study Closeout Report: This study does not have an expiration date. However, you are required to submit a study closeout report at the completion of the project

Sincerely,

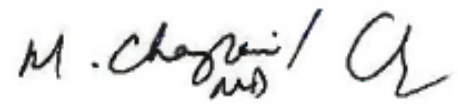

Mahesh Changlani, MD

Chairman

DHR Health Institute for Research and Development

Institutional Review Board 
University of St. Augustine for Health Sciences

Doctor of Nursing Practice Program

Evidence-Based Practice Review Council

1 University Blvd.

St. Augustine, FL 32086

February 19, 2020

Dear Marisa Raynaldo,

Your proposal titled Implementing Hospital-Acquired Pressure Injury (HAPI) Prevention

Program has been reviewed by the University of St. Augustine for Health Sciences Doctor of Nursing Practice Evidence-Based Practice Review Council (EPRC) and determined to:

meet the requirements for research as defined in the Federal Register. You must make adjustments to the proposal to reflect the DNP program requirements and resubmit for additional review. Work closely with your faculty member during this process.

_. _ not meet the requirements for research as defined in the Federal Register. Your proposal reflects an evidence-based practice change project. The proposal must be implemented as submitted (changes are not permitted). You may proceed to obtain approvals from the facility where the project will be implemented. Implementation may not begin until you are notified in writing by faculty that you may implement the project.

Questions regarding the USAHS approval process should be addressed to Dr. Douglas Turner at DTurner@usa.edu. Questions regarding the facility approval process should be addressed to course faculty.

Sincerely,

\section{Douglas Turner}

Douglas M Turner, PhD, DNP, RN, CNE, NE-BC, NEA-BC 


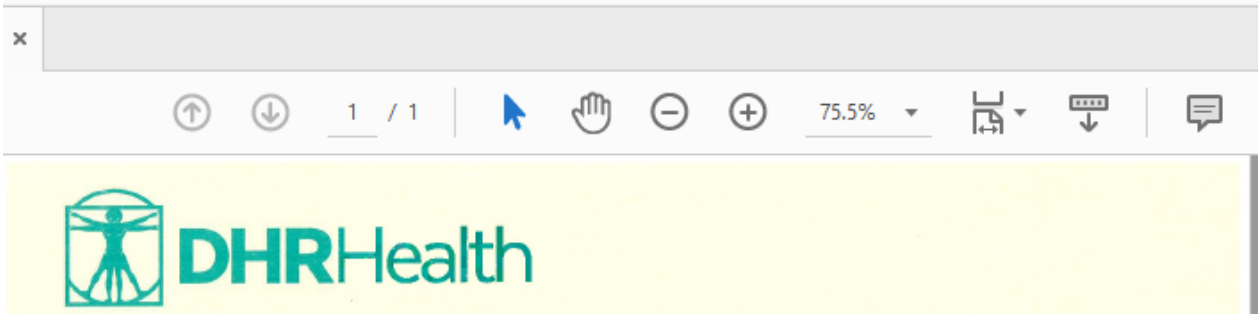

January 31,2020

RE: QI Project on Hospital-Acquired Pressure Injury (HAPI) Prevention

Dear IRB Committee Members,

We, at the nursing department, are excited to work with DNP Student, Marisa C. Raynaldo, MSN, RN and are supportive of her quality improvement project to help us reduce the incidence of Hospital-Acquired Pressure Injury. HAPI remains a challenge in the health care setting nationwide and we have seen incidences of HAPI in our facility, particularly in the critical care units. She is helping us put in place an evidenced-based HAPI prevention bundle as a quality improvement project. The evidence-based HAPI prevention bundle components are: education and training of staff, skin and risk assessment, moisture management, nutrition and hydration, and minimizing pressure, shear and friction.

Please do not hesitate to reach out with any questions.

Respectfully submitted.

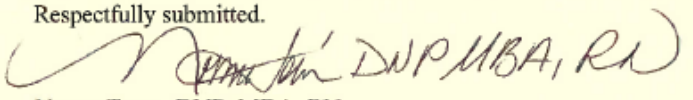

Norma Teran, DNP, MBA, RN

Executive Vice President- Chief Nursing Officer

956-362-7155 office

956-342-0197 cell 


\section{Appendix B: Summary of Primary Research Evidence}

\begin{tabular}{|c|c|c|c|c|c|c|}
\hline Citation & Sample size & $\begin{array}{l}\text { Design, } \\
\text { Level, } \\
\quad \& \\
\text { Quality } \\
\text { Grade }\end{array}$ & $\begin{array}{l}\text { Intervention } \\
\text { Comparison } \\
\text { Definitions }\end{array}$ & $\begin{array}{l}\text { Theoretical } \\
\text { Foundation }\end{array}$ & $\begin{array}{c}\text { Outcome } \\
\text { Definition }\end{array}$ & $\begin{array}{c}\text { Usefulness } \\
\text { Results } \\
\text { Key Findings }\end{array}$ \\
\hline $\begin{array}{l}\text { Amr, A., Yousef, A., Amirah, } \\
\text { M. (2017). A pre-post study } \\
\text { evaluating the effectiveness of a } \\
\text { new initiative, the "PRESSURE } \\
\text { Bundle," compared with } \\
\text { standard care in reducing the } \\
\text { incidence and prevalence of } \\
\text { sacral pressure ulcers in } \\
\text { critically ill patients in an } \\
\text { intensive care unit in Riyadh, } \\
\text { Saudi Arabia. Saudi Critical } \\
\text { Care Journal, 1(3), } 75 . \\
\text { doi:10.4103/sccj_29_7 }\end{array}$ & $\begin{array}{l}\text { Total } n=660 \\
\text { Control } \\
n=330 \\
\text { Intervention } \\
n=330\end{array}$ & $\begin{array}{l}\text { Pre-post } \\
\text { study } \\
\text { design } \\
\text { SORT } \\
\text { Level 3 } \\
\text { Quality: } \\
\text { B }\end{array}$ & $\begin{array}{l}\text { "Pressure" } \\
\text { bundle } \\
\text { prevention } \\
\text { measures that } \\
\text { consist of } \\
\text { positioning, risk } \\
\text { assessment, } \\
\text { elevation of heel, } \\
\text { skin assessment, } \\
\text { skin care and } \\
\text { protective } \\
\text { barriers, ultimate } \\
\text { nutrition, relief } \\
\text { of pressure, and } \\
\text { elevation of head } \\
<30 \text { degrees }\end{array}$ & $\begin{array}{l}\text { Not indicated, } \\
\text { however it } \\
\text { appears that the } \\
\text { authors may } \\
\text { have adapted } \\
\text { the holistic } \\
\text { theory whereby } \\
\text { the whole is } \\
\text { more than the } \\
\text { sum of its part. }\end{array}$ & $\begin{array}{l}\text { Incidence: the } \\
\text { number of new } \\
\text { cases of pressure } \\
\text { injuries that } \\
\text { developed in } \\
\text { adult ICU } \\
\text { patients at a given } \\
\text { time } \\
\text { Prevalence: the } \\
\text { number of new } \\
\text { and existing } \\
\text { pressure injuries } \\
\text { in adult ICU } \\
\text { patients at a given } \\
\text { time. }\end{array}$ & $\begin{array}{l}\text { Significant reduction in the } \\
\text { incidence }(\mathrm{n}=1,3 \%) \text { in } 2 \text { months } \\
\text { compared with standard care group } \\
(\mathrm{n}=16,4.6 \% ; p=<.001) \text { and } \\
\text { prevalence of sacral ulcers }(4.75 \%) \\
\text { compared with }(22.7 \%) \text { in the } \\
\text { standard group after } 2 \text { months } \\
(p=.001) \text { in critically ill patients }\end{array}$ \\
\hline $\begin{array}{l}\text { Anderson et al. (2015). } \\
\text { Universal pressure ulcer } \\
\text { prevention bundle with wound } \\
\text { ostomy continence nurse } \\
\text { (WOC).Journal of Wound, } \\
\text { Ostomy, and Continence } \\
\text { Nursing, 42(3), 217-225. } \\
\text { doi:10.1097/WON.00000000000 } \\
0109\end{array}$ & $\begin{array}{l}\text { Total } n=327 \\
\text { Pre- } \\
\text { intervention } \\
n=181 \\
\text { Post- } \\
\text { intervention } \\
n=146\end{array}$ & $\begin{array}{l}\text { Quasi- } \\
\text { experim } \\
\text { ental, } \\
\text { pre and } \\
\text { post } \\
\text { interven } \\
\text { tion } \\
\text { research } \\
\text { design } \\
\text { SORT } \\
\text { Level } 3\end{array}$ & $\begin{array}{l}\text { Universal } \\
\text { pressure ulcer } \\
\text { prevention } \\
\text { bundle (UPUPB) } \\
\text { combined with } \\
\text { proactive, semi- } \\
\text { weekly WOC } \\
\text { nurse rounds }\end{array}$ & $\begin{array}{l}\text { Not indicated, } \\
\text { although } \\
\text { Virginia } \\
\text { Henderson's } \\
\text { Need theory } \\
\text { can be a good } \\
\text { fit for the study }\end{array}$ & $\begin{array}{l}\text { Incidence: new } \\
\text { cases of pressure } \\
\text { ulcers that } \\
\text { developed in ICU } \\
\text { patients }\end{array}$ & $\begin{array}{l}\text { The UPUPB with WOC nurse } \\
\text { rounds resulted in a statistically } \\
\text { significant and clinically relevant } \\
\text { reduction in the incidence of } \\
\text { pressure ulcers }(p=.001)\end{array}$ \\
\hline
\end{tabular}




\begin{tabular}{|c|c|c|c|c|c|c|}
\hline & & $\begin{array}{l}\text { Quality: } \\
\text { B }\end{array}$ & & & & \\
\hline $\begin{array}{l}\text { Chaboyer, W., Bucknall, T., } \\
\text { Webster, J., McInnesg, E., } \\
\text { Gillespiea, B., Banks, } \\
\text { M.,...Wallis, M., (2016). The } \\
\text { effect of a patient centered care } \\
\text { bundle intervention on pressure } \\
\text { ulcer incidence (INTACT): A } \\
\text { cluster randomized trial. } \\
\text { International Journal of Nursing } \\
\text { Studies, 64, 63-71. } \\
\text { doi:10.1016/j.ijnurstu.2016.09.0 } \\
15\end{array}$ & $\begin{array}{l}\text { Total } \\
\mathrm{n}=1600 \text { adult } \\
\text { ICU patients } \\
200 \text { ICU } \\
\text { patients/hos } \\
\text { pital with } \\
\text { HAPI } n=8\end{array}$ & $\begin{array}{l}\text { Cluster } \\
\text { randomi } \\
\text { zed trial } \\
\text { SORT } \\
\text { Level 2 } \\
\text { Quality: } \\
\text { B }\end{array}$ & $\begin{array}{l}\text { PUPCB keep } \\
\text { moving; look } \\
\text { after your skin; } \\
\text { eat a healthy diet, } \\
\text { nurses and } \\
\text { patients training }\end{array}$ & $\begin{array}{l}\text { Founded on the } \\
\text { concept of } \\
\text { patient centered } \\
\text { care, patient } \\
\text { participation } \\
\text { and clinical } \\
\text { practice } \\
\text { guidelines }\end{array}$ & $\begin{array}{l}\text { Incidence: the } \\
\text { number of HAPU } \\
\text { measured by } \\
\text { daily inspection }\end{array}$ & $\begin{array}{l}\text { PUPCB was associated with a large } \\
\text { reduction in the incidence of } \\
\text { pressure ulcers. The difference was } \\
\text { not clinically significant due to } \\
\text { small sample size }\end{array}$ \\
\hline $\begin{array}{l}\text { Coyer, F., Gardner, A., } \\
\text { Doubrovsky, A., Cole, R., Ryan, } \\
\text { F. M., Allen, C., \& McNamara, } \\
\text { G. (2015). Reducing pressure } \\
\text { injuries in critically ill patients } \\
\text { by using a patient skin integrity } \\
\text { care bundle (InSPiRE). } \\
\text { American Journal of Critical } \\
\text { Care, 24(3), 199-209. } \\
\text { doi:10.4037/ajcc2015930 }\end{array}$ & $\begin{array}{l}\text { Total } n=207 \\
\text { Control } \\
\text { group } \\
n=102 \\
\text { Intervention } \\
n=105\end{array}$ & 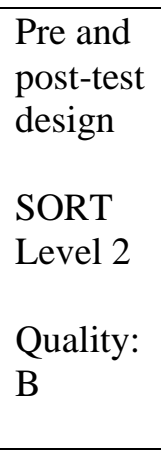 & $\begin{array}{l}\text { InSPiRE bundle: } \\
\text { interventional } \\
\text { skin integrity } \\
\text { bundle to reduce } \\
\text { pressure injuries } \\
\text { in critically ill } \\
\text { patients. }\end{array}$ & $\begin{array}{l}\text { Not indicated } \\
\text { May have } \\
\text { applied "all or } \\
\text { nothing" } \\
\text { approach based } \\
\text { on the holistic } \\
\text { theory of the } \\
\text { whole is more } \\
\text { than the total of } \\
\text { its parts }\end{array}$ & $\begin{array}{l}\text { Incidence: is the } \\
\text { number of newly } \\
\text { developed } \\
\text { pressure injuries } \\
\text { in a given time } \\
\text { multiplied by the } \\
\text { total number of } \\
\text { patients in the } \\
\text { same given time. }\end{array}$ & $\begin{array}{l}\text { Cumulative incidence of pressure } \\
\text { injuries was significantly lower in } \\
\text { the intervention group }(18.1 \%) \\
\text { compared to }(30.4 \%) \text { in the control } \\
\text { group for skin injuries }\left(x^{2}=4.3,\right. \\
p=.04) \text { and mucosal injuries } \\
(\mathrm{t}=3.27, p=<.01) \text { Significantly } \\
\text { fewer pressure injuries developed } \\
\text { over time in the intervention group } \\
\text { (log rank=11.842, } p=.02) \text {. }\end{array}$ \\
\hline $\begin{array}{l}\text { Tayyib, N., Coyer, F., \& Lewis, } \\
\text { P. A. (2016). Implementing a } \\
\text { pressure ulcer prevention bundle } \\
\text { in an adult intensive care. } \\
\text { Intensive and Critical Care } \\
\text { Nursing, 37, 27-36. }\end{array}$ & $\begin{array}{l}\text { Total } \\
\mathrm{n}=11 \mathrm{RNs}\end{array}$ & $\begin{array}{l}\text { Observa } \\
\text { tional } \\
\text { prospect } \\
\text { ive } \\
\text { study } \\
\text { design } \\
\text { SORT } \\
\text { Level } 2 \\
\text { Quality: } \\
\text { B }\end{array}$ & $\begin{array}{l}\text { Pressure ulcer } \\
\text { preventive } \\
\text { bundle }\end{array}$ & $\begin{array}{l}\text { Not known, } \\
\text { most likely } \\
\text { Roger's } \\
\text { diffusion } \\
\text { theory }\end{array}$ & $\begin{array}{l}\text { Incidence rate: } \\
\text { number of newly } \\
\text { developed } \\
\text { pressure ulcer in a } \\
\text { given time }\end{array}$ & $\begin{array}{l}\text { Reduction in the incidence of } \\
\text { PU/PI supports effective translation } \\
\text { of bundle into clinical practice } \\
\text { Compliance with the bundle } \\
\text { implementation was positively } \\
\text { related to the familiarity of the } \\
\text { personnel with the bundle in ICU }\end{array}$ \\
\hline $\begin{array}{l}\text { Tayyib, N., Coyer, F., \& Lewis, } \\
\text { P. A. (2015). A two-arm cluster } \\
\text { randomized control trial to }\end{array}$ & $\begin{array}{l}\text { Total } n=140 \\
\text { Control } \\
n=70\end{array}$ & $\begin{array}{l}\text { A two- } \\
\text { arm } \\
\text { cluster }\end{array}$ & $\begin{array}{l}\text { Pressure injury } \\
\text { prevention } \\
\text { bundle }\end{array}$ & $\begin{array}{l}\text { Not stated. } \\
\text { Most likely } \\
\text { Holistic theory }\end{array}$ & $\begin{array}{l}\text { Incidence: the } \\
\text { number of new } \\
\text { pressure injuries }\end{array}$ & $\begin{array}{l}\text { PU cumulative incidence was } \\
\text { significantly lower in the }\end{array}$ \\
\hline
\end{tabular}




\begin{tabular}{|c|c|c|c|c|c|c|}
\hline $\begin{array}{l}\text { determine the effectiveness of a } \\
\text { pressure ulcer prevention bundle } \\
\text { for critically ill patients. Journal } \\
\text { of Nursing Scholarship, } 47(3) \text {, } \\
\text { 237-247. doi: 10.1111/jnu.12136 }\end{array}$ & $\begin{array}{l}\text { Intervention } \\
\mathrm{n}=70\end{array}$ & $\begin{array}{l}\text { randomi } \\
\text { zed } \\
\text { experim } \\
\text { ental } \\
\text { control } \\
\text { trial. } \\
\text { SORT } \\
\text { Level 1 } \\
\text { Quality: } \\
\text { A }\end{array}$ & & $\begin{array}{l}\text { of the whole is } \\
\text { more than the } \\
\text { sum of its parts }\end{array}$ & $\begin{array}{l}\text { in adult ICU } \\
\text { patients in a given } \\
\text { time }\end{array}$ & $\begin{array}{l}\text { intervention group }(7.14 \%) \\
\text { compared to the control group } \\
(32.86 . \text { The intervention group } \\
\text { had significantly less Stage I ( } \mathrm{p} \\
=.002) \text { and Stage II PU } \\
\text { development }(\mathrm{p}=.026) \text {. }\end{array}$ \\
\hline $\begin{array}{l}\text { Roberts, S., Mcinnes, E., } \\
\text { Wallis, M., Bucknall, T., } \\
\text { Banks, M., \& Chaboyer, W. } \\
\text { (2016). Nurses' perceptions } \\
\text { of a Pressure ulcer prevention } \\
\text { care bundle: A qualitative } \\
\text { descriptive study. Bio } \\
\text { Medicine Central Nursing, } 15 \\
\text { (64). doi: } 10.1186 / \text { s12912- } \\
\text { 016-0188-9 }\end{array}$ & $\begin{array}{l}\text { total } \mathrm{n}=18 \\
\text { participants }\end{array}$ & $\begin{array}{l}\text { Qualitat } \\
\text { ive } \\
\text { descript } \\
\text { ive } \\
\text { researc } \\
\text { h } \\
\text { design } \\
\text { SORT } \\
\text { Level } 3 \\
\text { Quality } \\
\text { : B }\end{array}$ & PUPCB & $\begin{array}{l}\text { Not mentioned. } \\
\text { Most } \\
\text { likelyRoger's } \\
\text { theory of } \\
\text { diffusion }\end{array}$ & & $\begin{array}{l}\text { The increased awareness, } \\
\text { communication, and } \\
\text { participation in PUP care was } \\
\text { perceived positively } \\
\text { Nurses expressed that the } \\
\text { PUPCB was easily understood } \\
\text { and implemented. } \\
\text { Nurses emphasized the need for } \\
\text { implementation strategies that } \\
\text { include communication, } \\
\text { dissemination, leadership, and } \\
\text { keeping PUPCB simple to } \\
\text { strengthen partnership with the } \\
\text { nursing staff. }\end{array}$ \\
\hline
\end{tabular}

Legend: ICU: Intensive Care Unit; PUP: Pressure Ulcer Prevention; PUPCB: Pressure Ulcer Prevention Care Bundle; PI: Pressure Injury; PU: Pressure Ulcer; RNs: Registered Nurses; UPUPB: Universal Pressure Ulcer Prevention Bundle; WOC: Wound Ostomy Continence 
Summary of Systematic Reviews (SR)

\begin{tabular}{|c|c|c|c|c|c|c|c|}
\hline Citation & \begin{tabular}{|l|} 
Quality \\
Grade
\end{tabular} & Question & $\mid \begin{array}{l}\text { Search } \\
\text { Strategy }\end{array}$ & $\begin{array}{l}\text { clusion/ } \\
\text { xclusion } \\
\text { riteria }\end{array}$ & \begin{tabular}{|l} 
Data \\
Extraction \\
and \\
Analysis \\
\end{tabular} & Key F & $\begin{array}{l}\text { sefulness/Recommendation// } \\
\text { nplications }\end{array}$ \\
\hline $\begin{array}{l}\text { Tayyib, N., } \\
\text { \& Coyer, F. } \\
\text { (2016). } \\
\text { Effectiveness } \\
\text { of pressure } \\
\text { ulcer } \\
\text { prevention } \\
\text { strategies for } \\
\text { adult patients } \\
\text { in intensive } \\
\text { care } \\
\text { units. Joanna } \\
\text { Briggs } \\
\text { Institute } \\
\text { Database of } \\
\text { Systematic } \\
\text { Reviews and } \\
\text { Implementa- } \\
\text { tionnReports, } \\
\text { 14(3), 35-44. } \\
\text { doi:10.11124 } \\
\text { /jbisrir-2016- } \\
2400\end{array}$ & \begin{tabular}{|l} 
SORT \\
Level 1 \\
Quality: \\
A \\
\\
\end{tabular} & $\begin{array}{l}\text { Synthesize } \\
\text { and evaluate } \\
\text { the best } \\
\text { evidence on } \\
\text { the } \\
\text { effectivenes } \\
\text { s of single } \\
\text { intervention } \\
\text { to reduce } \\
\text { the } \\
\text { incidence } \\
\text { and } \\
\text { prevalence } \\
\text { of HAPU in } \\
\text { ICU in } \\
\text { comparison } \\
\text { to different } \\
\text { PU } \\
\text { prevention } \\
\text { strategies, } \\
\text { standard or } \\
\text { usual } \\
\text { practice. }\end{array}$ & $\begin{array}{l}\text { Database } \\
\text { utilized to } \\
\text { search for } \\
\text { literature on } \\
\text { interventions } \\
\text { to reduce the } \\
\text { incidence } \\
\text { and } \\
\text { prevalence of } \\
\text { hospital- } \\
\text { acquired } \\
\text { pressure } \\
\text { ulcers } \\
\text { (HAPU) in } \\
\text { Intensive } \\
\text { Care Unit } \\
\text { (ICU) } \\
\text { includes } \\
\text { CINAHL, } \\
\text { Medline } \\
\text { (PubMed) } \\
\text { journals, } \\
\text { Cochrane } \\
\text { Central } \\
\text { Register of } \\
\text { Controlled }\end{array}$ & $\begin{array}{l}\text { Included } \\
\text { were } \\
\text { quantitative } \\
\text { experiment } \\
\text { al studies, } \\
\text { randomized } \\
\text { controlled } \\
\text { trials } \\
\text { (RCT), } \\
\text { non- } \\
\text { randomized } \\
\text { controlled } \\
\text { trials, quasi } \\
\text { experiment } \\
\text { al, pre and } \\
\text { post, and } \\
\text { comparativ } \\
\text { e studies } \\
\text { published } \\
\text { in English } \\
\text { from 2000- } \\
\text { 2015 with } \\
\text { adult } \\
\text { participants } \\
\text { 18 years } \\
\text { and above }\end{array}$ & $\begin{array}{l}\text { Studies } \\
\text { were } \\
\text { retrieved } \\
\text { and } \\
\text { reviewed } \\
\text { by two } \\
\text { independe } \\
\text { nt } \\
\text { reviewers } \\
\text { prior to } \\
\text { inclusion } \\
\text { in the } \\
\text { review. } \\
\text { Using the } \\
\text { JBI- } \\
\text { MAStARI } \\
\text { appraisal } \\
\text { tool, } \\
\text { studies } \\
\text { were } \\
\text { included } \\
\text { in the } \\
\text { review } \\
\text { when they } \\
\text { met } 50 \% \\
\text { of the } \\
\text { criteria. }\end{array}$ & $\begin{array}{l}\text { Dressings- } 3 \text { studies reported } \\
\text { effectiveness of prophylactic application } \\
\text { of silicone foam dressing over the } \\
\text { sacrum with } p<.00001 \text {. Two studies } \\
\text { reported a significantly decreased } \\
\text { HAPU incidence in the intervention } \\
\text { group with application of silicone } \\
\text { dressing prophylactically on the heels } \\
\text { with } p=.002 \text { to } \\
\text { Nutrition- one study reported significant } \\
\text { association between specific } \\
\text { intervention diet and reduction of } \\
\text { HAPUs in patients with acute lung } \\
\text { injuries treated in ICU, with } p=.05, \\
\text { however, biases in the results were } \\
\text { reported as more participants with actual } \\
\text { PUs were included in the control group. } \\
\text { Repositioning Frequency- repositioning } \\
\text { every } 2 \text { hours was supported by } 2 \\
\text { studies in reducing the incidence of } \\
\text { HAPUs through different interventions. } \\
\text { Using turn team strategy composed of } \\
\text { two-trained patient care assistants } \\
\text { showed significant improvement in the }\end{array}$ & $\begin{array}{l}\text { Develop a Risk } \\
\text { assessment of skin and } \\
\text { tissues (RAS) for ICU } \\
\text { patients that can be } \\
\text { incorporated into the } \\
\text { study protocol to identify } \\
\text { patients at risk for PU } \\
\text { development, and assist } \\
\text { in the appropriate } \\
\text { implementation of PU } \\
\text { strategies } \\
\text { Developing effective skin } \\
\text { care strategies } \\
\text { specifically in the sacral } \\
\text { areas of ICU patients by } \\
\text { conducting additional } \\
\text { studies that manage skin } \\
\text { moisture, skin hygiene, } \\
\text { skin dehydration and } \\
\text { maintenance of natural } \\
\text { skin ph. } \\
\text { Evaluation of the most } \\
\text { effective support surfaces } \\
\text { in PU prevention in } \\
\text { effective sample sizes, }\end{array}$ \\
\hline
\end{tabular}




\begin{tabular}{|c|c|c|c|c|c|c|c|}
\hline$\overline{\text { Citation }}$ & $\begin{array}{l}\text { Quality } \\
\text { Grade }\end{array}$ & Question & $\begin{array}{l}\text { Search } \\
\text { Strategy }\end{array}$ & $\begin{array}{l}\text { Inclusion/ } \\
\text { Exclusion } \\
\text { Criteria }\end{array}$ & \begin{tabular}{|l|} 
Data \\
Extraction \\
and \\
Analysis \\
\end{tabular} & Key Findings & $\begin{array}{l}\text { Usefulness/Recommendation/ } \\
\text { Implications }\end{array}$ \\
\hline & & & $\begin{array}{l}\text { Trials, Web } \\
\text { of Science, } \\
\text { Embase, } \\
\text { ERIC, } \\
\text { Scopus, and } \\
\text { Mednar } \\
\text { between } \\
2000 \text { and } \\
2015 \text {. The } \\
\text { search for } \\
\text { unpublished } \\
\text { studies } \\
\text { consisted of } \\
\text { New York } \\
\text { Academy of } \\
\text { Medicine }\end{array}$ & $\begin{array}{l}\text { admitted in } \\
\text { the ICU. } \\
\text { Studies } \\
\text { included } \\
\text { have } \\
\text { HAPU } \\
\text { incidence, } \\
\text { prevalence, } \\
\text { PI severity, } \\
\text { time to } \\
\text { occurrence } \\
\text { and number } \\
\text { of PIs per } \\
\text { patient } \\
\text { listed as } \\
\text { primary } \\
\text { outcome } \\
\text { measures. }\end{array}$ & $\begin{array}{l}\text { To assess } \\
\text { the } \\
\text { studies' } \\
\text { heterogen } \\
\text { eity, } \\
\text { population } \\
\text { interventio } \\
\text { n, and } \\
\text { outcome } \\
\text { were } \\
\text { considered } \\
\text { and } \\
\text { presented } \\
\text { in } \\
\text { narrative } \\
\text { form. ORs } \\
\text { with a CI } \\
\text { of } 95 \% \\
\text { were } \\
\text { calculated } \\
\text { when } \\
\text { possible } \\
\text { for binary } \\
\text { outcomes. } \\
\text { A third } \\
\text { reviewer } \\
\text { resolved } \\
\text { any } \\
\text { disagreem } \\
\text { ents. }\end{array}$ & $\begin{array}{l}\text { incidence of HAPUs between pre and } \\
\text { post implementation } p<.0001 \text {. } \\
\text { However, the studies did not indicate } \\
\text { compliance to turn team strategy or } \\
\text { utilization of other prevention strategies } \\
\text { at the time of the studies. } \\
\text { Positioning the patient in bed- prone } \\
\text { position combined with application of } \\
\text { silicone dressing was reported to be } \\
\text { associated with significantly greater } \\
\text { HAPU development compared to a } \\
\text { supine position in the first seven days of } \\
\text { patient admission p=.05; however, the } \\
\text { three studies did not indicate the } \\
\text { frequency of repositioning the patient, } \\
\text { and other supportive PU prevention } \\
\text { strategies, and the angle of the lower } \\
\text { part of the body. } \\
\text { Support surfaces-alternating pressure } \\
\text { mattress significantly lowered the } \\
\text { incidence of HAPUs, stage II or greater } \\
\text { compared to using foam overlay } \\
\text { mattress, } p=.038 ; \text { however, the studies } \\
\text { acknowledged that the small sample } \\
\text { sizes and undeclared compliance to } \\
\text { other prevention strategies could be } \\
\text { noteworthy limitations. } \\
\text { Medical device related PUs-significant } \\
\text { difference in the incidence of urinary- }\end{array}$ & $\begin{array}{l}\text { fewer options of support } \\
\text { surface products and } \\
\text { consistent use of the PU } \\
\text { staging system as an } \\
\text { outcome measure. } \\
\text { Utilization of } \\
\text { prophylactic silicone } \\
\text { foam dressing over the } \\
\text { sacrum and heels. } \\
\text { As offloading pressure on } \\
\text { heels is a standard of } \\
\text { care, a further study is } \\
\text { recommended to compare } \\
\text { if the outcomes with the } \\
\text { use of silicone dressings } \\
\text { on the heels is better than } \\
\text { the outcomes of heel } \\
\text { offloading devices. } \\
\text { More studies to validate } \\
\text { the effects of different } \\
\text { prevention strategies } \\
\text { implemented such as high } \\
\text { protein diet with } \\
\text { multivitamins, polarized } \\
\text { light, timing of } \\
\text { tracheostomy, different } \\
\text { education and training } \\
\text { strategies }\end{array}$ \\
\hline
\end{tabular}




\begin{tabular}{|c|c|c|c|c|c|c|c|}
\hline$\longdiv { \text { Citation } }$ & $\begin{array}{l}\text { Quality } \\
\text { Grade }\end{array}$ & Question & $\begin{array}{l}\text { Search } \\
\text { Strategy }\end{array}$ & \begin{tabular}{|l} 
Inclusion/ \\
Exclusion \\
Criteria
\end{tabular} & $\begin{array}{l}\text { Data } \\
\text { Extraction } \\
\text { and } \\
\text { Analysis } \\
\end{array}$ & Key Findings & $\begin{array}{l}\text { Usefulness/Recommendation/ } \\
\text { Implications }\end{array}$ \\
\hline & & & & & & $\begin{array}{l}\text { catheter related PUs between groups } \\
\text { with } p=.002 \text {, when the area around the } \\
\text { entry point to the catheter was washed } \\
\text { three times a day. } \\
\text { Significant improvement in the } \\
\text { incidence of medical related device for } \\
\text { non-invasive ventilation was reported } \\
\text { with the use of prototype face masks } \\
\text { compared to traditional face masks } p<\text {. } \\
\text { o01. Using different protective dressings } \\
\text { like transparent film and hydrocolloid } \\
\text { with traditional masks showed a } \\
\text { significant difference in the incidence of } \\
\text { device related PUs between groups, } p=\text {. } \\
\text { o01. } \\
\text { Patients who had traumatic brain injury } \\
\text { and had early tracheostomy }<8 \text { days of } \\
\text { ICU admission has significantly lowered } \\
\text { incidence of HAPUs } p=.001 ; \text { however, } \\
\text { it was unclear how the outcomes were } \\
\text { objectively measured in a reliable way } \\
\text { and there was no mention of any other } \\
\text { PU preventive strategies for both } \\
\text { groups. } \\
\text { Educational strategies- significant } \\
\text { reduction of the HAPU incidence was } \\
\text { reported after implementation of } 2 \text {-hours } \\
\text { seminar for ICU nurses to increase }\end{array}$ & $\begin{array}{l}\text { Frequent repositioning, 2- } \\
\text { hour repositioning, is } \\
\text { considered to be a } \\
\text { standard of care to } \\
\text { prevent PU development } \\
\text { Include monitoring the } \\
\text { degree of compliance to } \\
\text { either the strategy itself or } \\
\text { to other PU prevention } \\
\text { strategies and utilization } \\
\text { of standardized PU } \\
\text { assessment and staging to } \\
\text { increase the } \\
\text { understanding of the } \\
\text { different prevention } \\
\text { strategies. } \\
\end{array}$ \\
\hline
\end{tabular}




\begin{tabular}{|c|c|c|c|c|c|c|c|}
\hline Citation & $\begin{array}{l}\text { Quality } \\
\text { Grade }\end{array}$ & Question & $\begin{array}{l}\text { Search } \\
\text { Strategy }\end{array}$ & $\begin{array}{l}\text { Inclusion/ } \\
\text { Exclusion } \\
\text { Criteria }\end{array}$ & \begin{tabular}{|l} 
Data \\
Extraction \\
and \\
Analysis \\
\end{tabular} & Key Findings & $\begin{array}{l}\text { Usefulness/Recommendation/ } \\
\text { Implications }\end{array}$ \\
\hline
\end{tabular}

Legend: Intensive Care Unit; PUP: Pressure Ulcer Prevention; PUPCB: Pressure Ulcer Prevention Care Bundle; PI: Pressure Injury; PU: Pressure Ulcer; RNs: Registered Nurses; UPUPB: Universal Pressure Ulcer Prevention Bundle; WOC: Wound Ostomy Continence 


\section{Appendix C: Project Schedule}

\begin{tabular}{|c|c|c|c|c|c|c|c|c|c|c|c|c|c|c|c|c|c|c|c|c|c|c|c|c|}
\hline & \multicolumn{8}{|c|}{$\begin{array}{c}\text { NUR7801 September 2019-Dec, } \\
2020\end{array}$} & \multicolumn{8}{|c|}{$\begin{array}{l}\text { NUR7802 January 2020-April, } \\
2020\end{array}$} & \multicolumn{8}{|c|}{ NUR7803 May 2020-August, 2020} \\
\hline 㝵 & $\frac{\bar{y}}{3}$ & $\frac{m}{y}$ & $\frac{n}{8}$ & $\frac{\sqrt{2}}{8}$ & $\begin{array}{l}a \\
\frac{4}{8} \\
3\end{array}$ & $\begin{array}{l}= \\
\frac{\pi}{8} \\
\frac{d}{3}\end{array}$ & $\frac{m}{\frac{n}{8}}$ & $\begin{array}{l}\frac{n}{2} \\
\frac{y}{2} \\
\frac{d}{3}\end{array}$ & $\frac{7}{\frac{y}{d}}$ & $\begin{array}{l}m \\
\frac{y}{8} \\
\frac{8}{3}\end{array}$ & $\frac{n}{8}$ & $\frac{5}{8}$ & $\begin{array}{l}a \\
\frac{y}{8} \\
3\end{array}$ & $\begin{array}{l}= \\
\bar{y} \\
0 \\
8 \\
3\end{array}$ & $\frac{\frac{m}{2}}{\frac{y}{8}}$ & $\frac{n}{\frac{n}{8}}$ & $\frac{7}{8}$ & $\frac{m}{8}$ & $\frac{n}{8}$ & $\frac{1}{8}$ & $\begin{array}{l}a \\
\frac{y}{8} \\
3\end{array}$ & $\begin{array}{l}= \\
\frac{y}{8} \\
z\end{array}$ & $\begin{array}{l}\frac{m}{y} \\
\frac{y}{d} \\
\frac{d}{3}\end{array}$ & $\frac{n}{\frac{n}{d}}$ \\
\hline $\begin{array}{l}\text { Meet with } \\
\text { preceptor }\end{array}$ & $X$ & $\mathrm{X}$ & $\mathrm{X}$ & $\mathrm{X}$ & $\mathrm{X}$ & $\mathrm{X}$ & $\mathrm{X}$ & $\mathrm{X}$ & & & & & & & & & & & & & & & & \\
\hline $\begin{array}{l}\text { Prepare project } \\
\text { proposal }\end{array}$ & & & $\mathrm{X}$ & & $\mathrm{X}$ & & $\mathrm{X}$ & & & & & & & & & & & & & & & & & \\
\hline $\begin{array}{l}\text { Final Project } \\
\text { proposal }\end{array}$ & & & & & & & & $\mathrm{X}$ & & & & & & & & & & & & & & & & \\
\hline IRB to USA & & & & & & & & & $\mathrm{X}$ & $\mathrm{X}$ & & & & & & & & & & & & & & \\
\hline $\begin{array}{l}\text { IRB to } \\
\text { DHRHealth }\end{array}$ & & & & & & & & & & $\mathrm{X}$ & $\mathrm{X}$ & $\mathrm{X}$ & & & & & & & & & & & & \\
\hline $\begin{array}{l}\text { BUNDLE } \\
\text { IMPLEMENTATI } \\
\text { ON PROCESS: } \\
\text { a. } \\
\text { Pressure } \\
\text { Injury } \\
\text { Policy } \\
\text { Revision/ } \\
\text { Approval } \\
\text { b. } \\
\text { Education, } \\
\text { skills } \\
\text { training \& } \\
\text { competen } \\
\text { cy } \\
\text { c. Bundle } \\
\text { Implemen } \\
\text { tation to }\end{array}$ & & & & & & & & & & & & & $\mathrm{X}$ & $X$ & $X$ & $\mathrm{X}$ & $\mathrm{X}$ & $\mathrm{X}$ & $\mathrm{X}$ & $X$ & $X$ & & & \\
\hline
\end{tabular}




\begin{tabular}{|c|c|c|c|c|c|c|c|c|c|c|c|c|c|c|c|c|c|c|c|c|c|c|c|c|}
\hline & \multicolumn{8}{|c|}{$\begin{array}{l}\text { NUR7801 September 2019-Dec, } \\
2020\end{array}$} & \multicolumn{8}{|c|}{$\begin{array}{l}\text { NUR7802 January 2020-April, } \\
2020\end{array}$} & \multicolumn{8}{|c|}{ NUR7803 May 2020-August, 2020} \\
\hline 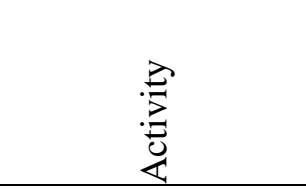 & $\begin{array}{l}\bar{y} \\
\frac{\bar{d}}{3} \\
3\end{array}$ & $\begin{array}{l}\frac{m}{8} \\
\frac{u}{0} \\
3\end{array}$ & $\begin{array}{l}n \\
\frac{n}{8} \\
\frac{d}{3}\end{array}$ & $\frac{\sqrt{2}}{3}$ & $\begin{array}{l}a \\
\frac{1}{8} \\
3\end{array}$ & $\begin{array}{l}\overline{7} \\
\frac{y}{0} \\
\frac{d}{3}\end{array}$ & $\begin{array}{l}\frac{m}{4} \\
\frac{y}{8} \\
\frac{0}{3}\end{array}$ & $\begin{array}{l}\frac{n}{2} \\
\frac{x}{8} \\
\frac{8}{3}\end{array}$ & $\begin{array}{l}\vec{y} \\
\frac{\Delta}{8} \\
3\end{array}$ & $\begin{array}{l}m \\
\frac{y}{8} \\
3\end{array}$ & $\begin{array}{l}n \\
\frac{y}{8} \\
z \\
3\end{array}$ & $\begin{array}{l}\frac{y}{8} \\
\frac{0}{3} \\
3\end{array}$ & $\begin{array}{l}\frac{a}{0} \\
\frac{0}{3}\end{array}$ & $\begin{array}{l}= \\
\frac{y}{0} \\
0 \\
3\end{array}$ & $\begin{array}{l}\frac{m}{2} \\
\frac{x}{d} \\
\frac{D}{3}\end{array}$ & $\begin{array}{l}\frac{n}{y} \\
\frac{y}{8} \\
\frac{8}{3}\end{array}$ & $\frac{\sqrt{2}}{\sqrt[0]{0}}$ & $\begin{array}{l}\frac{n}{8} \\
\frac{d}{3} \\
\frac{8}{3}\end{array}$ & $\begin{array}{l}n \\
\frac{n}{8} \\
\frac{0}{3}\end{array}$ & $\frac{\sqrt{y}}{8}$ & $\begin{array}{l}\frac{a}{8} \\
\frac{0}{3} \\
3\end{array}$ & $\begin{array}{l}z \\
\frac{u}{\Delta} \\
\vec{d} \\
3\end{array}$ & $\begin{array}{l}\frac{m}{2} \\
\frac{u}{8} \\
\frac{D}{3}\end{array}$ & $\begin{array}{l}n \\
\frac{y}{8} \\
\frac{d}{3}\end{array}$ \\
\hline population & & & & & & & & & & & & & & & & & & & & & & & & \\
\hline Data Collection & & & & & & & & & & & & & & & & & & & & & & $X$ & & \\
\hline Data Analysis & & & & & & & & & & & & & & & & & & & & & & & $\mathrm{X}$ & \\
\hline Dissemination & & & & & & & & & & & & & & & & & & & & & & & & $X$ \\
\hline
\end{tabular}




\section{Appendix D: Budget}

\begin{tabular}{|c|c|c|c|}
\hline EXPENSES & & REVENUE & \\
\hline Direct & & Billing & NA \\
\hline Salary and benefits & Built in & Grants & NA \\
\hline $\begin{array}{l}\text { Training \& Competency } \\
\text { check off } \$ 35 / \mathrm{H} \times 2 \mathrm{H}=70 \mathrm{H} \\
\text { for } 60 \text { staff }\end{array}$ & $\$ 2,450$ & Institutional budget support & $\$ 5,000$ \\
\hline Services & NA & & \\
\hline Statistician & $\$ 300$ & $\begin{array}{l}50 \% \text { Reduction in PI (from } 40 \mathrm{PI} \\
\text { to } 20 \mathrm{PI} \text { ) }\end{array}$ & $\$ 300,000$ \\
\hline & & & \\
\hline \multicolumn{4}{|l|}{ Indirect } \\
\hline Overhead & Built In & & \\
\hline Total Expenses & $\$ 2,750$ & Total Revenue & $\$ 305,000$ \\
\hline
\end{tabular}




\section{Appendix E: Evaluation Tools}

Data Collection Form

\begin{tabular}{|l|l|l|l|l|l|l|l|l|l|}
\hline Patient & Age & Diagnosis & LOS & $\begin{array}{l}\text { Brad } \\
\text { en } \\
\text { Risk } \\
\text { Score } \\
\text { s }\end{array}$ & $\begin{array}{l}\text { Presence } \\
\text { of } \\
\text { Medical } \\
\text { Device }\end{array}$ & $\begin{array}{l}\text { Co- } \\
\text { morbidity }\end{array}$ & $\begin{array}{l}\text { Incidence } \\
\text { of PIs }\end{array}$ & $\begin{array}{l}\text { Number } \\
\text { \& Stage } \\
\text { of PIs }\end{array}$ & $\begin{array}{l}\text { Location of PIs } \\
\text { ID\# }\end{array}$ \\
\hline
\end{tabular}

Compliance Checklist

\begin{tabular}{|l|l|l|l|l|l|}
\hline Staff ID\# & $\begin{array}{l}\text { Documented } \\
\text { risk \& skin } \\
\text { assessment }\end{array}$ & $\begin{array}{l}\text { Documented } \\
\text { moisture } \\
\text { management }\end{array}$ & $\begin{array}{l}\text { Documented } \\
\text { nutritional } \\
\text { consult }\end{array}$ & $\begin{array}{l}\text { Documented } \\
\text { minimizing } \\
\text { pressure, shear } \\
\text { \& friction }\end{array}$ & $\begin{array}{l}\text { Documented } \\
\text { attendance of staff } \\
\text { to education \& } \\
\text { training }\end{array}$ \\
\hline$\# 001$ & Yes/No & Yes/No & Yes/No & Yes/No & Yes/No \\
\hline
\end{tabular}

